\title{
Critical review and methodological issues in integrated life-cycle analysis on road networks
}

Hasan, U. and Whyte, A. and Al Jassmi, H.

Hasan, U. and Whyte, A. and Al Jassmi, H. 2019. Critical review and methodological issues in integrated life-cycle analysis on road networks. Journal of Cleaner Production. 206: pp. 541-558.

\section{Word Count:}

14583. 


\begin{abstract}
Life-cycle management of road network projects traditionally emphasise material production and construction stages, with less attention given to usage stage and functionality improvement. Increasingly there is a need to address: inconsistencies in cost attribute selection; adjusting for uncertainties and costs; clarifying system boundaries; data sources; functional units and regional or temporal applicability of life-cycle frameworks. The current study focuses on a critical literature review of life-cycle cost analysis (LCCA) and life-cycle assessment (LCA) research published in the last decade (post 2008) towards identification of research gaps. Accurately analysing all life-cycle stages, feedback loops, future cash and resource flows, and interlinking performance with overall sustainability can aid the decision-making process towards sustainable alternatives for constructing new, or rehabilitating existing roads. This review finds that the use of recycled materials, base/sub-base stabilisers and asphalt binder replacement has the potential of energy saving ( $\geq 34 \%$ or $3.1 \mathrm{TJ}$ ), mitigating landfill disposal issues, and greenhouse gas load reduction ( $\geq 34.5 \% \mathrm{CDE}$ ). Lack of real world LCCA-LCA application and stakeholder prejudice against recycled material usage are addressable by better stakeholder (decision-makers and road users) engagement via a social component. The proposed enhancements identified in this study can increase LCA/LCCA attraction to policy-makers, planners and users and ultimately ensure a more sustainable asset.
\end{abstract}

Keywords: road network sustainability; asphalt pavements; life-cycle assessment; recycled materials; GHG emissions.

\title{
1. Introduction
}

Due to unprecedented population growth and ongoing influx of people and businesses towards urban areas, roadways often face traffic congestions causing time-delays, pollutant emissions, added fuel and vehicle operational costs, noise pollution and deterioration of the road networks. Issues such as limitation of funds, lack of political/social interest and subjectivity of opinion dominates the decision-making process to create and maintain infrastructure in perpetuity. Principles of control and system-style life-cycle engineering management are generally under applied. Traditionally, project studies are often conducted during the feasibility stage of an asset's design and much emphasis is placed upon the initial costs. However, the whole costs of low-specification design, construction without adequate quality management systems and sporadic rather than controlled inspection, as well as unstructured operation, maintenance and rehabilitation (OM\&R) regimes continue to cause concern (Hood et al., 2018). Significant monetary benefits exist where cost analyses are performed for the entire life of a road network asset (e.g., pavements, highways, bridges and other roadside components) towards increased investment and long-term benefit to users.

Life-cycle cost analysis (LCCA) is the conventional procedure for the evaluation of the financial benefits and returns from any investment by analysing its future expenditures along with the initial costs. Whilst the application of LCCA in road construction has been given considerable attention during the past decades, only 
limited practical application has been attained so far (Cabeza et al., 2014). Coupled with the principle of costeffectiveness, is the idea of sustainability which adds to the traditional balance of time, quality and cost of construction investment. Adding sustainability into the equation introduces the comprehensive criteria of evaluating road investment decisions, either for "new" road networks or "rehabilitation" of deteriorating assets, against environmental, social, and even political and administrative perspectives. Roadway projects can then be sustainably and cost-effectively procured, designed, constructed, managed and maintained and then reintegrated or recycled. It means that if the sustainability justifications are added to the economical or monetary criteria, the needs of users can be better met and further benefits may be achieved if the analysis is performed for the entire life cycle of the road network assets.

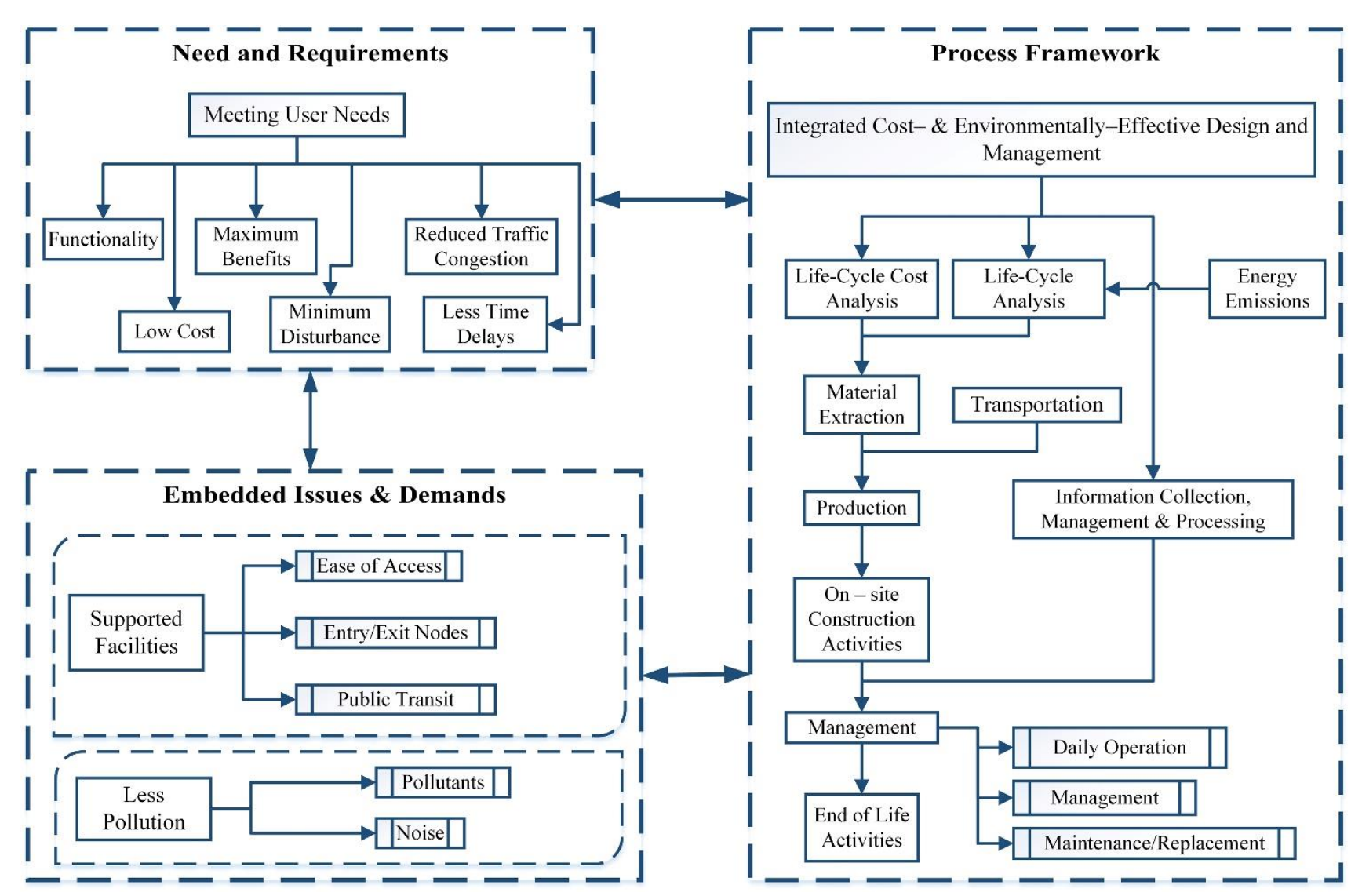

Figure 1 Schematic of processes in infrastructure design and management

Life-cycle assessment (LCA) is a known methodology for evaluating environmental impacts related to energy consumption, greenhouse gas and pollutant emissions of processes and products (ISO 14040, 2006). Any integrated design and management of a typical road network project generally considers three main subjects: identifying the main problem that requires an investment; the embedded hidden issues; and, the problem-solving process or methodology (Figure 1). The success of any road network project, therefore, depends upon the cumulative efficiency of these three primary components, to balance cost and environmental targets and (government) agency's adherence to code and standards' legislation. 
Integration of the two road infrastructure design and management assessment approaches, LCCA and LCA, and the direction of respective cost and environmental burdens alongside the effect of vehicle-surface interactions on fuel consumption and wear and tear of tyres during the usage stage of a pavement require acknowledgement within an analysis framework. It is also essential for government authority decision-makers to consider all design and management aspects, such as; traffic congestion; cost and environmental risks; road ownership and user costs; vehicle operation and ownership cost; currency fluctuations; and, environmental loads during a whole-life of the road asset. However, researcher projects tend to be limited in the number of aspects and scope of the life-cycle stages considered (AzariJafari et al., 2016).

The purpose of the current study is to provide a state-of-the-art review and analysis of the existing literature in the wider field of LCCA and LCA of road network projects to highlight the critical aspects, identify the hotspots in current processes which can be improved upon to increase the robustness of the frameworks and facilitate the government authority and private planning/consulting stakeholders to achieve whole-life cost and overall sustainability goals. Once the critical aspects are identified for achieving overall system sustainability of road and transport projects; the energy, human capital and other resources can optimised to reduce excessive environmental burdens towards cleaner production of road network projects. Literature review methodology adopted here consists of collecting peer-reviewed research papers published in the last decade, after 2008 (through Google Scholar and ScienceDirect databases), to review the latest research work conducted on lifecycle management of road network projects. The adopted methodology is roughly based on Guo et al. (2018), expanded to include the most recent and definitive research published on road networks elements; inclusive of pavements, highway (roadside) components and bridges to capture the wider extent of the transport and road research field.

The articles were filtered based on the road elements and life-cycle stages addressed relative to respective cost, pollutants and energy consumption across large-scale projects comparing critical indicators, scope, and framework of peer-reviewed studies to uncover findings that may improve the cost and environmental performance of these road assets. Two sub-stages in the processing stage, LCCA and LCA of individual studies are discussed in context of stakeholder needs, the embedded issues in the study system boundary, and the frameworks proposed for problem solution. This is a significant contribution of the current study as it addresses the three (cost, environmental and social) sustainability issues of road network assets to cover the extent of perceived process problems in management of road network projects.

The main purpose of this paper is to review the state of existing literature and identify the critical processes and stages for effective asset management and life-cycle assessment of road network projects towards overall cost, social and environmental sustainability. Researchers have performed individual extensive reviews of studies on the use of recycled materials (Anthonissen et al., 2016; Balaguera et al., 2018; Gautam et al., 2018) in road projects, attributes for life-cycle costs (Babashamsi et al., 2016), LCA as a project procurement and planning tool (Butt et al., 2015; AzariJafari et al., 2016), significance of traffic/transit load and patterns in the overall life-cycle impact of road networks (Inyim et al., 2016) and the social and policy concerns (Santos et al., 
2010; Jiang et al., 2017). On the other hand, studies on quantifying/minimising the environmental burden, e.g., particulate matter pollutants (Pant and Harrison, 2013) and fuel consumed by the traffic (Rahman et al., 2017) were reviewed by other researchers. This paper further develops on the findings of these studies to propose cleaner production of road networks as a policy issue; highlight the significance of life-cycle environmental and socio-economic burden from the vehicles and the use of recycled materials to promote sustainable development. It also presents an overall picture of the energy, cost and resource inflows and outflows across the whole-life of road networks in addition to the critical attributes, data resources for life-cycle analyses, common mitigation, recycling and mixing strategies utilised and standards of practices.

\section{Process Framework: LCCA in road network projects}

Researchers considering the practical application of LCCA for the design and rehabilitation of road and infrastructure projects, such as Zimmerman et al. (2010) defined this whole-cost application as an evaluation of all anticipated costs incurring during the desired service-life of the asset so that different alternatives can be compared and assessed through equivalent parameters, and a feasible course of actions deduced.

\subsection{Conceptual basis and stages in LCCA}

The reliability of any LCCA-based (whole-cost) framework or model is influenced by the accuracy of the data collected as well as projection of any future costs that may occur in the considered life-cycle of the asset. The exact determination of future expenditures can often be uncertain due to market variables and risks such as recession and variations in the velocity of distant cash flows (Galí, 2015). Economists as well as asset managers, when accounting for alternate investments during the planning and design of an asset, often discount future costs after $n$ years with a constant or variable discount rate to give a more realistic magnitude of the asset's operational, maintenance, user and social costs (including environmental costs) in terms of the present value "PV" (Goh and Yang, 2009). Equation (1) shows this relation for initial costs of $C_{i n}$ and costs $C_{t}$ for a year $t$ if the discount rate is $i$ (American Standard for Testing of Materials (ASTM), 2015).

$$
P V=\sum_{t=0}^{n} \frac{C_{t}}{(1+i)^{t}} ; \quad \text { for } C_{t}=C_{o}(1+e)^{t} ;
$$

Equation (1)

LCCA results for any road design alternative are influenced by the fluctuations in the discount rate and may even be further influenced by local currency inflation and risks (Wu et al., 2017). Discount rates applied by the private agencies usually reflect risk-free annual return rate (akin to government treasury bonds), while public agencies base it on their cost of raising capital. An empirical rule of thumb (Equation (2)) provided by the Royal Institution of Chartered Surveyors acknowledges these factors and may be included in off-the-shelf packages or any LCCA spreadsheet developed for the analysing life-cycle costs occurring at various stages in a road project's life (Whyte, 2015a). 
Discount rate $=($ Treasury bond return rate - Inflation $)$

$$
+[0.5 \times(\text { Average equity return }- \text { Treasury bond })]
$$

Equation (2)

Additionally, Equation (3) is used to determine the escalated rates in future.

$$
\begin{aligned}
& A=P V\left\{\frac{\left[i(1+i)^{n}\right]}{\left[(1+i)^{n}-1\right]}\right\} \\
& C_{l}=C_{a c}+C_{e n}+C_{i n s}+C_{o p}+C_{m}+C_{r n}-V_{r}
\end{aligned}
$$

Equation (4)

The life-cycle cost $\left(C_{l}\right)$ of a road asset can, therefore, be given by Equation (3) (Whyte, 2015a); where: acquisition cost of materials and land is $C_{a c} ; C_{e n}$ represents energy costs; construction and installation costs are $C_{i n s}$ and $C_{o p}$ is the asset operational and usage cost. Routine minor maintenance costs are $C_{m}, C_{r n}$ is the renewal cost, and any salvage or residual value is represented by $V_{r}$. The costs are converted to present worth by using Equation (1). This means that the traditional inputs to any LCCA model are fixed, discrete values, discounted to equivalent units to produce preconceived results. The conversion or discounting of future expenditures to present value or worth is a procedure in which the results of a cost analysis over the long-term are uncertain when selecting the best alternative, solely based on an investment-return methodology.

Generally, the common elements of LCCA models developed for road project investment decisions tend to observe a multi-tier procedure (Figure 2), whereas the critical economic indicators are not generally prioritised. Input variables, such as initial costs, operation and occupancy costs, maintenance and repair costs, social and hidden costs, externalities and incomes, analysis period, end-of-life costs and compensation for inflation, depreciation of money with time are fixed, based upon past studies and traditional LCCA approaches (Wennström and Karlsson, 2016) to address cost optimisation problems of road maintenance and pavement design. The need for construction of new roads or rehabilitation of an existing pavement structure forms the basis on which the objectives of a functional product ${ }^{1}$ are developed and the scope and boundary of the project are established. The life-cycle inventory data for the specific road design alternatives, i.e., available resources and manpower are assessed next to perform cost computations for the road projects.

\footnotetext{
${ }^{1}$ The term product used herein is intended to include both goods and services, and is also used in such context by the ISO 14040 guideline (ISO, 2006). A product system model, therefore, represents the processes involved during the entire lifecycle of a product, and respective inflows-outflows of capital, resources and energy.
} 


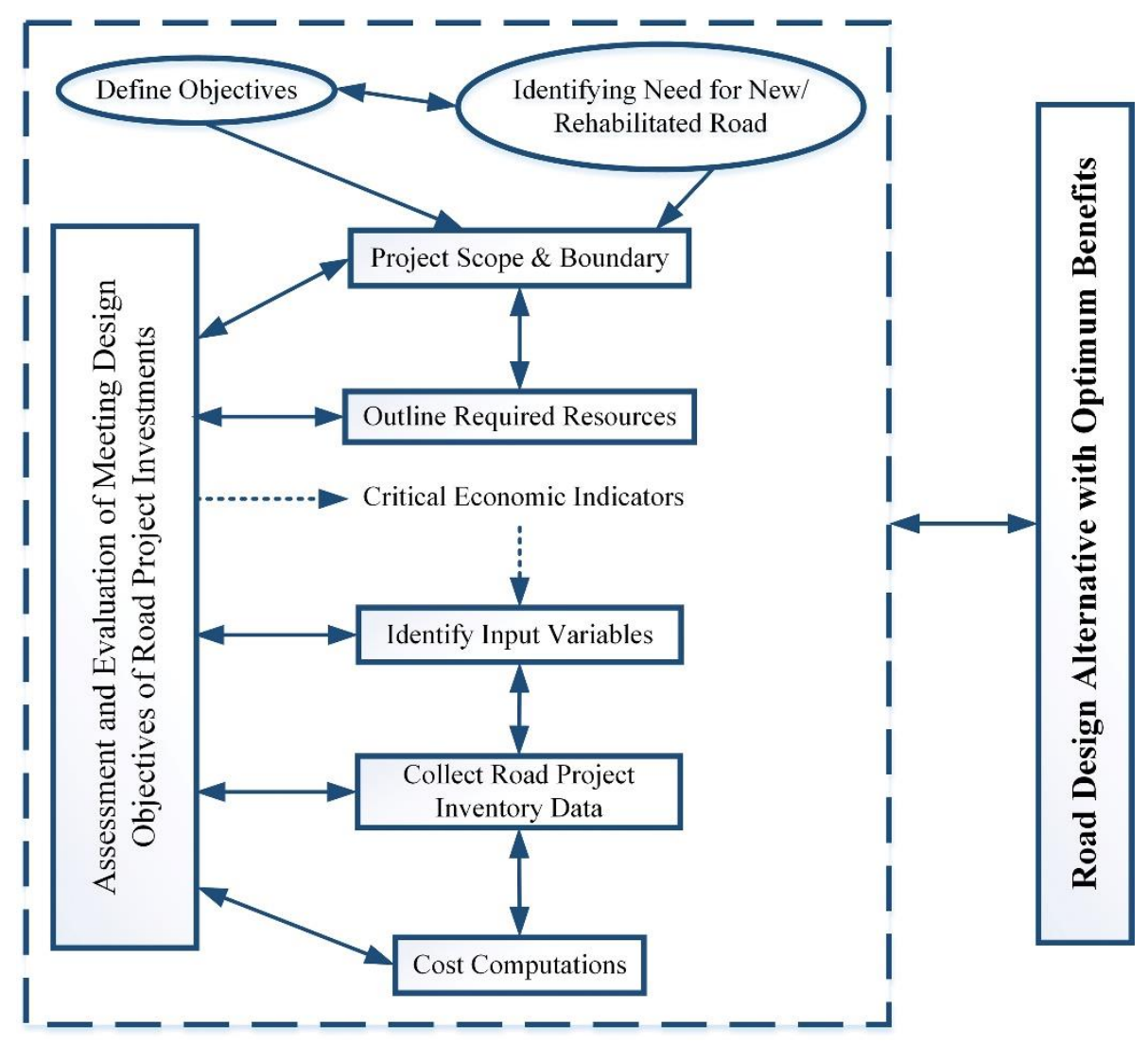

Figure 2 Stages in a conventional LCCA for investment decision-making on road projects

\subsection{Cost aggregation: Future cash-flows}

The inflows and outflows of resources and critical variables occurring during any of the several stages within a project's estimated life-cycle are synthesised in a database, and the costs for a practicable range of "fitfor-purpose" alternatives are calculated. Whilst costs to mitigate and address technical measures to find environmental compliances for noise and particulate matter are assessed generally, environmental benefit and energy inflows-outflows are reserved for LCA consideration (Section 3). After compensating for uncertainties and discounting cost, preferred fit-for-purpose alternatives are then categorised based upon cost, benefit and feasibility contributions. The alternative with the optimum benefits can then be deduced based upon the impact categorisation produced by the LCCA. It should be noted that LCCA does not yield a direct fixed alternative or prioritise the implemented option (Alqahtani and Whyte, 2013, 2016). Nonetheless, LCCA does aid decisionmakers in assessing the need-cost-benefit paradigm for the road asset. The following text covers the recent state of the art studies conducted on the development of LCCA frameworks specifically targeted towards pavements, highways and bridge projects. The discussion below covers LCCA (whole-cost) application across various stages within the asset's life-cycle and the different frameworks proposed in the existing research literature. 


\subsection{Stakeholder expenses: Costs to users}

The concept of getting the most benefits for the least amount of investment is not a novel idea within the domain of the road network projects. Researchers (Jingning, 2015; Mirza and Ali, 2017) have advocated the intermingling of LCCA-effective design and OM\&R practices with those of value engineering to improve the decision-making paradigm. Further argument by Alqahtani and Whyte (2016) advocates for the calculation of indirect socio-economical, environmental and road-user indirect costs, such as: accessibility and comfort; accident and safety; time-delays; and, vehicle operational costs due to congestions, detours and work zone conditions. The road network user costs (Equation (4)) have to be added to the assets' life-cycle cost estimates, calculated based on Equation (3), for best estimation of the stakeholder expenses.

User costs $=C_{\text {time-delay costs }}+C_{\text {vehicle opreration costs }}$ Equation (5)

\subsection{Stakeholder expenses: Budgetary costs of road agencies}

Due to the limitation of the funds available to many municipal agencies, private financing of public infrastructures provides an alternate option. However, in order to attract the private investors, the economic feasibility evaluation should address the involved uncertainties (both cost estimation- and performance-related) and risks (financial and payment, pre- and post-contractual and political risks) when evaluating the potential returns (Giang and Pheng, 2015), as direct correlation between risks and return exists. It is also noteworthy at this stage that the investment goals of private investors may not necessarily align with the political, publicity and administrative objectives of the government municipal authority; and, may be more inclined towards materialising a solid client retention and consumer market expansion.

One notable example, for road and transport projects, is the case of Public Transport Authority of Western Australia, where approximately $65 \%$ of public transit and road projects were approved by government stakeholders, despite projecting a negative net present value, a potential rejection marker for private investors (Whyte, 2015a). The government authorities seeking partnership with private investors may fail to convey their objective of maximum social benefits to the investors while campaigning for a higher initial cost for a later return, nonetheless user retention of road projects through expanding transit clients may be more comprehensible. This client or commuter attraction is probably achievable by passenger engagement and need identification so that the government or private capital can be best targeted towards providing services that, not only results in whole-life social benefits from the road and transit asset, but also expand clientele of the services provided by involving users in the decision-making process (Hasan et al., 2018a). Supplementary studies targeting this specific objective of identifying client needs (Hasan et al., 2018b) should, therefore, be performed prior to any design or life-cycle study to ensure the success of the project. 


\subsection{Maintenance and rehabilitation $(M \& R)$ costs}

The application of an LCCA framework on M\&R projects addressing deteriorating road network elements was explored in a study by Choi et al. (2015a) on highway M\&R works. The authors collected extensive data containing 190,000 roadways datasets from the Texas Department of Transportation's pavement information management system regarding 39,000 highway sections and 103 influencing factors to perform regression and cluster analysis. The study noted sensitivity of LCCA analyses to cost indicators and traffic loading and underlying road network peculiarities. Mobility trends, i.e., mode choice of commuters (Hasan et al., 2018a), fluctuate over the road network life-cycle. In order for any transit system to act as a quality service providing platform to its consumers, the infrastructure that supports it must be well-maintained. Cost of maintaining the road network is dependent upon several factors attributed to its contributing elements; e.g., age and thickness of pavement, provision of highways and bridges (facilitating high-speed corridors), perceived traffic congestion during maintenance activities, temporal variations, political, administrative and investment objectives as well as average annual average daily traffic load.

\subsection{Frameworks and critical parameters for LCCA}

Researchers have long investigated pavements and other elements of a road network and adopted LCCA to compare design alternatives. However, these LCCA studies are somewhat diverse, and present an eclectic mix of parameters deemed critical for achieving cost optimisation when designing or maintaining the road network assets. The breadth of published literature is still lacking in succinct guidelines and indicator databases comparable across the different studies and so, towards the state of the art analyses presented here, Table 1 provides a summary of the key LCCA studies detailing multiple iterations and combinations for road networks projects towards system transparency and a mirroring of stakeholder objectives. 
Table 1 Summary of commonly cited studies on LCCA of various elements of road network projects

\begin{tabular}{|c|c|c|c|c|c|c|c|c|c|c|c|c|c|c|c|c|c|c|c|c|c|c|c|c|}
\hline \multirow[b]{2}{*}{ Researchers } & \multicolumn{4}{|c|}{$\begin{array}{c}\text { Issues } \\
\text { addressed }\end{array}$} & \multicolumn{6}{|c|}{ Cost parameters } & \multicolumn{5}{|c|}{ Uncertainty } & \multicolumn{3}{|c|}{$\begin{array}{c}\text { Time and } \\
\text { traffic }\end{array}$} & \multicolumn{6}{|c|}{ Design parameters } \\
\hline & 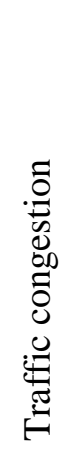 & 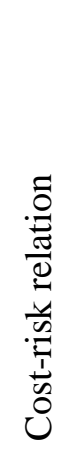 & 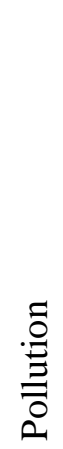 & 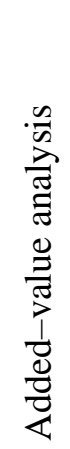 & 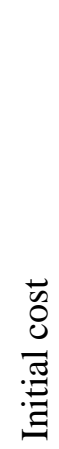 & 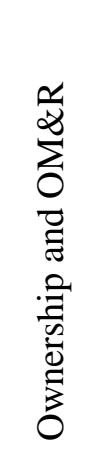 & 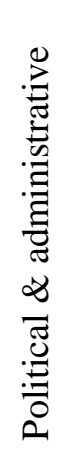 & 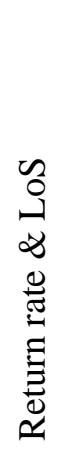 & 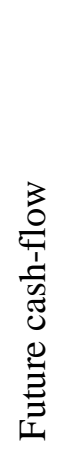 & 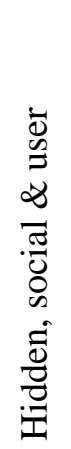 & 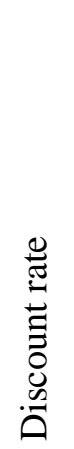 & 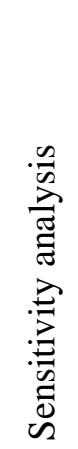 & 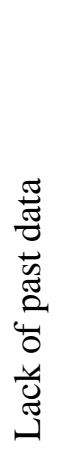 & 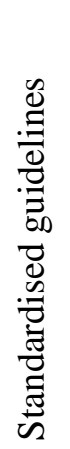 & 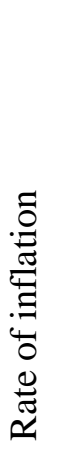 & 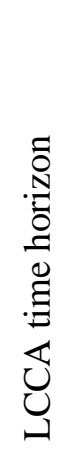 & 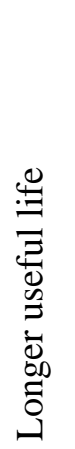 & 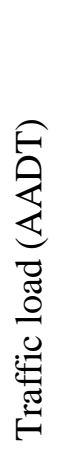 & 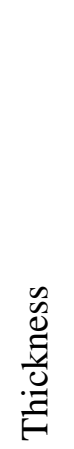 & 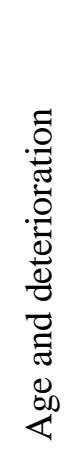 & 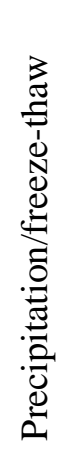 & 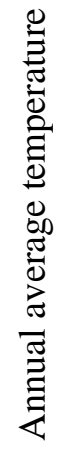 & 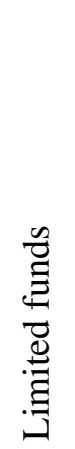 & 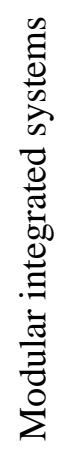 \\
\hline
\end{tabular}

Chen and Ni (2018)

Maintenance \& surface roughness:

highways and roads

Lee et al. (2018)

Rehabilitation: highways

Batouli et al. (2017)

Construction \& extension: highway

Celauro et al. (2017)

Construction \& maintenance: roads

Trigaux et al. (2017)

Construction \& maintenance: urban

and suburban roads
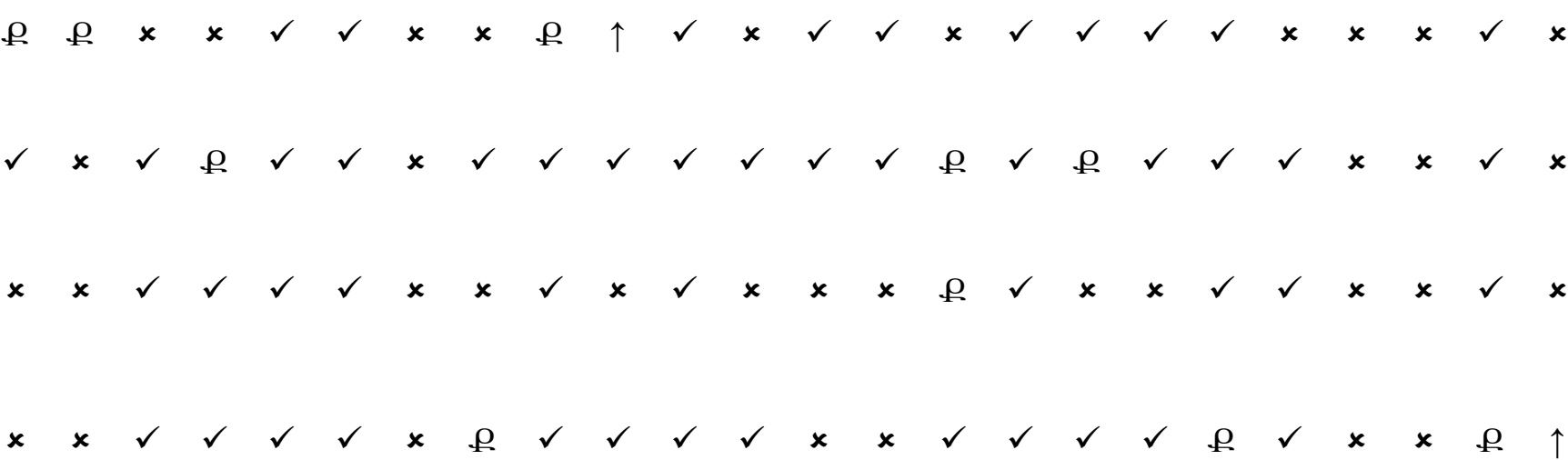
Simões et al. (2017)

Micro-surfacing Preventive

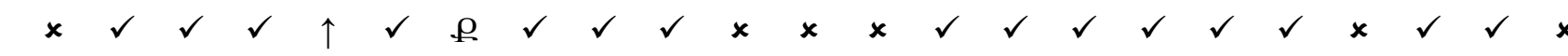

maintenance: roads

Wu et al. (2017)

Preventative maintenance: pavements

Jannat and Tighe (2016)

Maintenance \& rehabilitation: highway

Wennström and Karlsson (2016)

Rehabilitation: pavement

Choi et al. (2015a)

Rehabilitation: highway

Han and Do (2015)

Maintenance simulation: highways

Qiao et al. (2015)

Maintenance and climate change cost: highways

Du et al. (2014)

Procurement: bridges

Goh and Yang (2014)

Sustainability cost: highways

Mirzadeh et al. (2014)

Construction and rehabilitation: roads

Noori et al. (2014)

Reflective cracking mitigation: roads

I

$\begin{array}{llllllllllllllllllllllllllll}\rho & \times & \rho & x & \checkmark & \checkmark & x & \rho & \checkmark & x & \checkmark & x & \checkmark & \checkmark & x & \checkmark & \checkmark & \checkmark & \checkmark & \checkmark & x & x & \checkmark & x\end{array}$

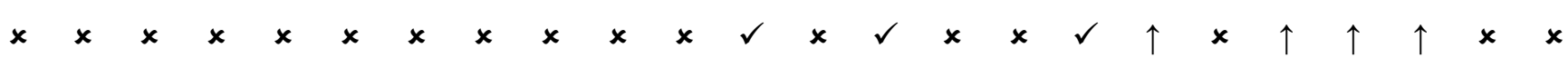

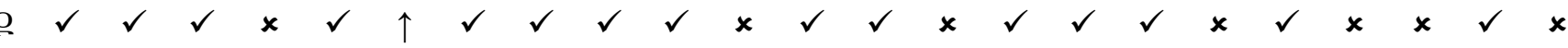

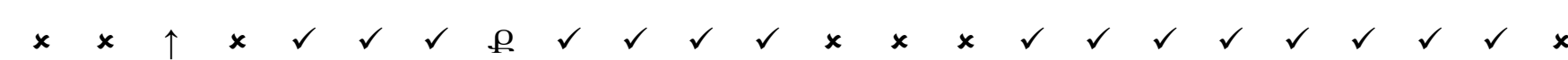

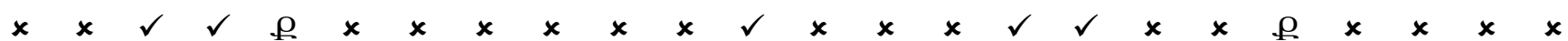
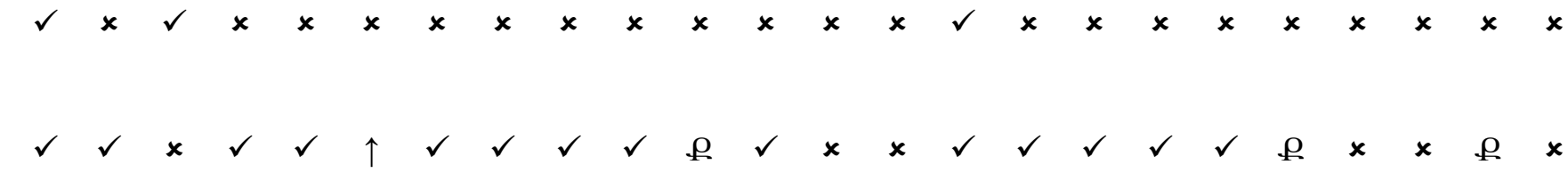
Safi et al. (2014)

Procurement: bridge

$x \times \sqrt{x}$

$\times \quad x$

$x \quad x$

$x \quad x$

$x \quad x$

$x \quad x$

Goh and Yang (2009)

Sustainability: roads

$\times \quad \times \quad \checkmark \quad \times \quad \times \quad \checkmark$

$x$

$x$

$\checkmark x$

× $x \times x \times x$

Key: $\quad \checkmark=$ used/addressed, $\mathbf{\rho}=$ partially addressed, needs further work, $\mathbf{x}=$ Unaddressed/Needed $\uparrow=$ recognised as the leading factor 


\subsection{Summary and gaps from the reviewed Roads LCCA frameworks}

Real world project-level analysis of the 18 studies cited above, finds adherence to numerous respective (varied) guidelines and industry norms from around the world, as key to an LCCA methodology for roads. For simplification of analysis complexity, it is suggested that any proposed LCCA framework should include prominent items from the key variable groups identified in the table above. The exact variable selection is dependent upon the complexity of project, expert appraisal, and severity of the required cost optimisation endeavours. Following these guidelines, detailed document analysis of the above published literature shows that:

- Ownership and $O M \& R$ costs form part of a cost parameter matrix in a majority of the essential roads' studies $(\sim 75 \%)$. The cost to acquire the road network asset on part of the municipal agency is critical for the decision-makers analysing completeness cost of the project, however, consistency in cost analysis needs to be maintained to include the $\mathrm{OM} \& \mathrm{R}$ cost, as a higher acquisition cost may be justifiable by a reduction in the future management and operation expenditure later.

- Risks associated with road network investments are explored in only three studies where they are the primary focus of the analysis. Capital investments are affected by several interdependent factors such as temporal variations, traffic growth patterns, fluctuations in discount rates and deterioration of pavement material which creates an inherent cost risk perceivable by decision-makers. Transparency of any applied LCCA framework is susceptible to an appropriate acknowledgement of the involved risks in the cost allotment to different project design alternatives.

- Uncertainty and market fluctuations were acknowledged in almost all ( 80\%) of the key road's whole cost studies. Recommendations made on the basis of a LCCA framework are not only susceptible to the adopted discount rate (acknowledged in $\sim 70 \%$ of research) and inflation rate (considered in $\sim 40 \%$ ) of the analysis currency, but, also susceptible to uncertainty as a result of a lack of historical data or low "quality" data collected for analysis. On the other hand, an abundance of past data of construction and rehabilitation activities can present a variety of options to the decision-makers for any potential road network projects. Due to perceived misalignment between various government and public stakeholders on the best course of action, a general lack of trust and uncertainty on LCCA results is still noted to exist in real world projects.

- User costs and hidden social costs were generally addressed (60\%), however, more emphasis was placed on agency-side costs of ownership and maintenance (75\%). Nonetheless, user costs may be critical for future studies; recent work by Wennström and Karlsson (2016) attributed a majority of costs towards the road users as illustrated in Figure 3. Decisions to constrain the scope of analysed variable constructs to agencyside parameters may be attributed to a general lack of data at the various life-cycle stages of the asset under consideration.

- Political and administrative issues cost and dollar-value (i.e., fiscal translation) of pollutant generation (taking lead in only one study) need to be included in the LCCA framework as environmental sustainability 
not only mirrors overall design objectives of embedded projects' needs, but also increase the robustness of the LCCA process. Partially inspired by the marginal monetary utility maximisation principles of economics, optimising the per-dollar value of road networks is an important parameter for municipal authorities, and so easily comprehensible by the general public. A dollar value of pollutants generated as a result of human activities (i.e., roads here) per tonne of greenhouse gases (GHG), human productivity lost and costs in recuperating from adverse health impacts affect the robustness of any LCCA framework and can greatly help to rank valuation of the different project alternatives.

- Implemented LCCA processes also need to be attentive to future cash-flows, traffic load patterns, limited funds available to the agency, time horizon of the analysis and cost associated with different aspects of each primary road network element. Constrained budgets and sustainability goals of municipal agencies necessitate the use of transparent frameworks accounting for cash-returns and dynamic traffic flows in addition to maintaining (limited) controls on mass mobility to achieve future-proofing.

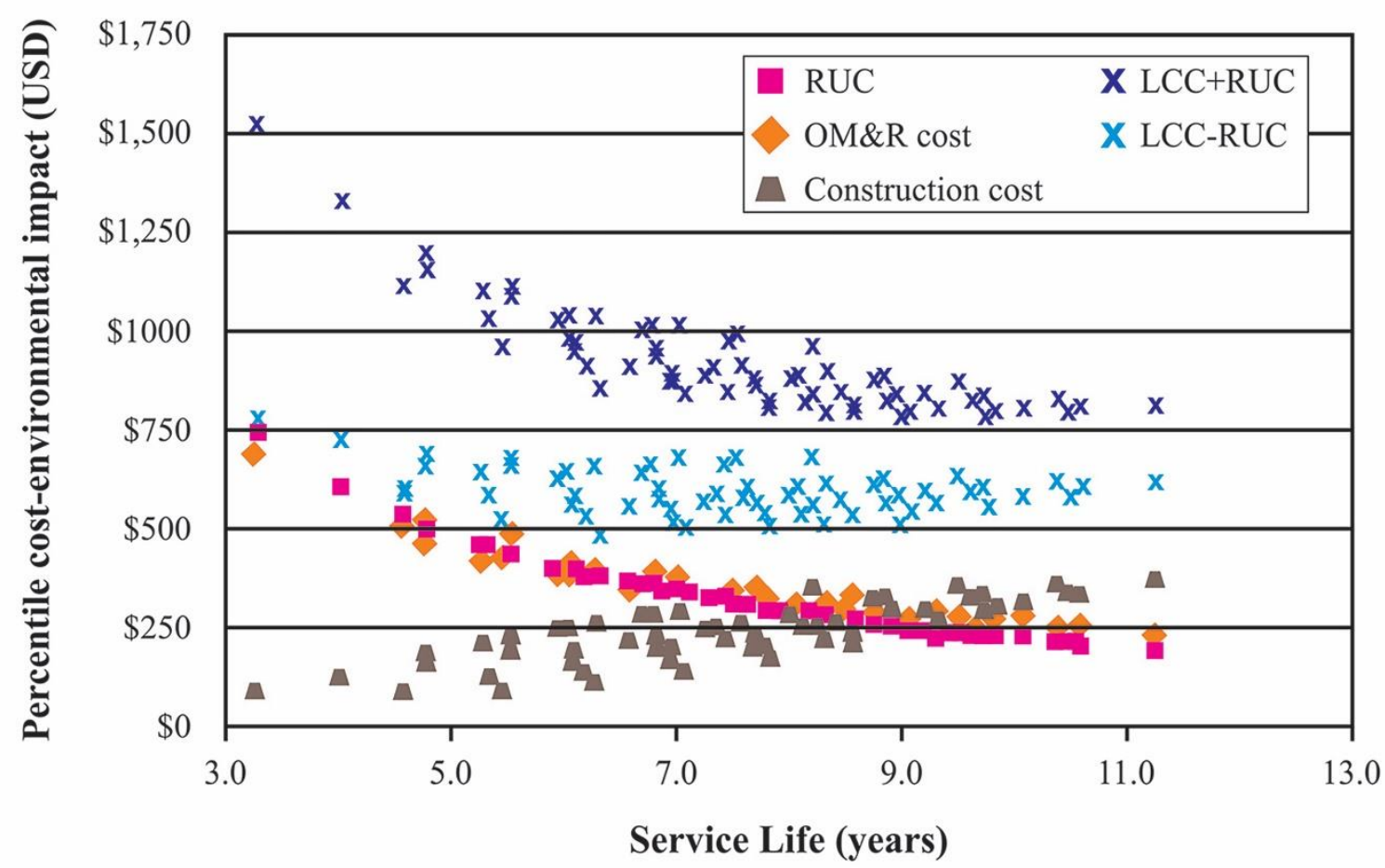

Figure 3 Percentile trade-off between cost-environment of road projects (adapted from Wennström and Karlsson (2016))

Generally, government authorities commissioning design and performing decisions on maintenance and operation of road assets need decision support tools throughout the assets' life-cycle to optimise the costs. LCCA considers all costs occurring during the effective project life, however, these costs need to be properly discounted to net present value and market fluctuations, uncertainties and risks should be acknowledged in project-specific LCCA models or spreadsheets developed to compare the cost components. These factors may also be significant when comparing the use of recycled materials (Hasan et al., 2016a) during any stage in the road assets' life-cycle, often motivated by environmental goals and reducing "eco-loading" of the construction 
activities. For example, Whyte (2015a) compared virgin materials (virgin limestone, hot/warm-mix asphalt) against recycled materials in a heavily trafficked Western Australia road. The general conclusions proposed more environmentally friendly options as slightly cheaper provided the application cannot be precluded by haulage. As these costs largely target the ownership, operation, maintenance and rehabilitation costs to the government agency; costs to road users in terms of direct vehicle operation cost, value of time lost in congestion around construction zones or under-capacity roads incapable of handling large traffic loads, not least the indirect impact on human health and environmental toxicity, need to be accounted for (further discussed in Section 3.4). Nonmonetary scores such as the environmental and social benefits may produce a larger difference between the virgin and recycled material options, often justified through LCA analysis tools.

\section{Process Framework: LCA in road network projects}

Life-cycle assessment (LCA), initially coined by SETAC in 1990 (Fava et al., 2014), is the methodological evaluation of environmental weightings of a product by systematic quantification of impacts such as resource consumption and depletion, eutrophication, climate change, ozone depletion, noise pollution and other direct and indirect implications of human activities on the ecosystem (ISO 14040, 2006; SAIC, 2006; Svoboda, 2006) generated over the entire life-cycle; or "cradle to cradle/grave".

\subsection{Conceptual basis and phases in life-cycle assessments:}

The conceptual basis for LCAs has been developed over decades with the I/O evaluation of net energy analysis and then assessing production processes both directly and indirectly responsible for generation of energy and waste emissions (Green and Lepkowski, 2006). LCA adopts a life-cycle perspective to quantify the resource and energy consumption and wastes (e.g., GHG) emitted in the environment, which increases interest in developing an LCA-based framework for built assets (Sharma et al., 2011). The process framework largely based upon SETAC and ISO 14040 asserts that the sustainability assessment of a product must acknowledge impact across three dimensions; economic, environmental and social. Four distinctive systematic phases of an iterative LCA approach are: outlining goal and scope, compilation of life-cycle inventory (LCI), life-cycle impact assessment (LCIA) and the last phase of interpretation.

Goal and scope outlining involves the identification and report of the extent of a product system including the processes expected later in its life-cycle. A familiar feature of this phase in the description of a functional unit $^{2}$, system boundaries ${ }^{3}$, categories of impact (e.g., social, economic and environmental) and alternative scenarios. LCI compilation is the tabulation and quantification of the collected information regarding the energy

\footnotetext{
${ }^{2}$ As defined by ISO 14040, "A functional unit is a measure of the performance of the functional outputs of the product system", and may use quantification of materials or the service provided, e.g., a roadway is intended for transportation of people and goods and may have extended sub-functions of providing less congested, quicker, smoother and easier transportation depending upon its design.

${ }^{3}$ Recommended cut-off criteria for constraining the elements to be modelled for representation of a product system, based on energy/resources, and environmental impacts.
} 
and resource exchanges (inflows-outflows) with the environment and waste emissions over the project's life in a product system (Whyte, 2015b). After the compilation, the LCIA phase involves conversion of inventory into systematic estimates of environmental impacts weighted and evaluated based upon analytical indicators. The last phase of interpretation is actually an iterative process in practice, in the sense that it follows and precedes the three other LCA phases after every consecutive iteration of the assessment process. Even though the primary focus of LCA is to provide analysts with quantitative data on environmental impacts associated with the processes upstream, decision-makers are often encouraged to conclude recommendations based upon LCIA and inventory data in conjunction with the sub-functions and impact categories and not just the magnitude of the energy/resource flow and waste generation.

\subsection{Data collection, data quality check, material control and product declarations}

One of the primary challenges in real-world application of any LCA methodology is defining the scope, source and quality of the LCIA inventory data that needs to be collected for identifying the environmental burden generated across the different stages of a road network asset. Industrial confidentiality related to upstream case-specific historical data and the cost of gathering high quality and detailed LCA data for a construction project (Treloar et al., 2004) may be challenging for any road agency in applying LCA for decisionmaking process. On the other hand, uncertainties in the collected LCIA data may be detrimental to the calculated environmental performance of the different alternatives for the road asset case study being analysed by the road management agency. These issues with data collection, quality check and system boundaries were further highlighted by Yu et al. (2018). They note that as the existing pavement LCA studies rely on different energy intensity values data resources to calculate the energy consumption associated with concrete and/or asphalt pavement production, the estimated values may lead to fluctuations. Moreover, scarcity of certain construction materials and local resource depletion concerns in a case study region, transportation distance, mixing techniques, equipment and heating etc., may also influence the corresponding calculations.

Such issues, identified prior to conduction of an LCA study increases the stakeholder confidence and ensures adequate decision-making process for best road alternative selection. Primary data sources should be used where possible and missing data may be complimented by secondary resources from peer-reviewed literature as prevalent in the research on road materials (e.g., Moretti et al. (2017)). The system boundary, including selection of road life-cycle stages, may be based upon the standardised performance data sheets such as environmental product declaration standards. Environmental product declarations (EPDs) are international third-party verified standardised (ISO 14025, 2006; CEN EN 15804, 2013; ISO 21930, 2017) data sheets for the environmental performance of different impact categories regulated by product category rules (PCRs); i.e.; climate change (global warming potential) value, ozone depletion value and acidification potential etc.; of the road alternatives. In a standardised LCA methodology, the government road management agency defines the PCRs prior to conduction of an LCA. Studies such as Baker et al. (2016) have used Type III, i.e., product-specific, EPDs to define LCA boundary report the LCA study results. 


\subsection{Construction material selection: LCA approach in pre-construction stages}

The traditional aim behind conducting LCAs is to improve the overall performance of a product in terms of environmental impacts, and as such an earlier estimate in design and construction procurement procedures may produce benefit. Pavements, highways and bridges form a critical portion of the road networks. Therefore, they account for a significant part of energy/resource consumptions, emission of GHGs such as $\mathrm{CO}_{2}, \mathrm{CO}, \mathrm{NO}_{\mathrm{x}}, \mathrm{O}_{3}$ and black carbon and other volatile organic compounds generated by the road network projects. Fuglestvedt et al. (2008) have observed that the global radiative forcing corresponding to the pavements alone for the year 2000 were $150 \mathrm{~mW} / \mathrm{m}^{2}$ and since industrial times, road networks may have accounted for approximately $31 \%$ and $15 \%$ of the total ozone and carbon dioxide forces due to human activities, from material extraction and production stages to the final salvage or reuse. Figure 4 below, highlights some of the key energy burden work. Biswas (2014) in his study comparing the use of recycled materials against virgin materials in roadway construction in Australia, found that 180.6 tonnes of CDE and 10.67 TJ energy was consumed during an urban pavement's life-cycle, while Choi et al. (2015b) found 4390.774 tonnes CDE for a JRCP pavement consuming $49.8 \mathrm{TJ}$ energy.

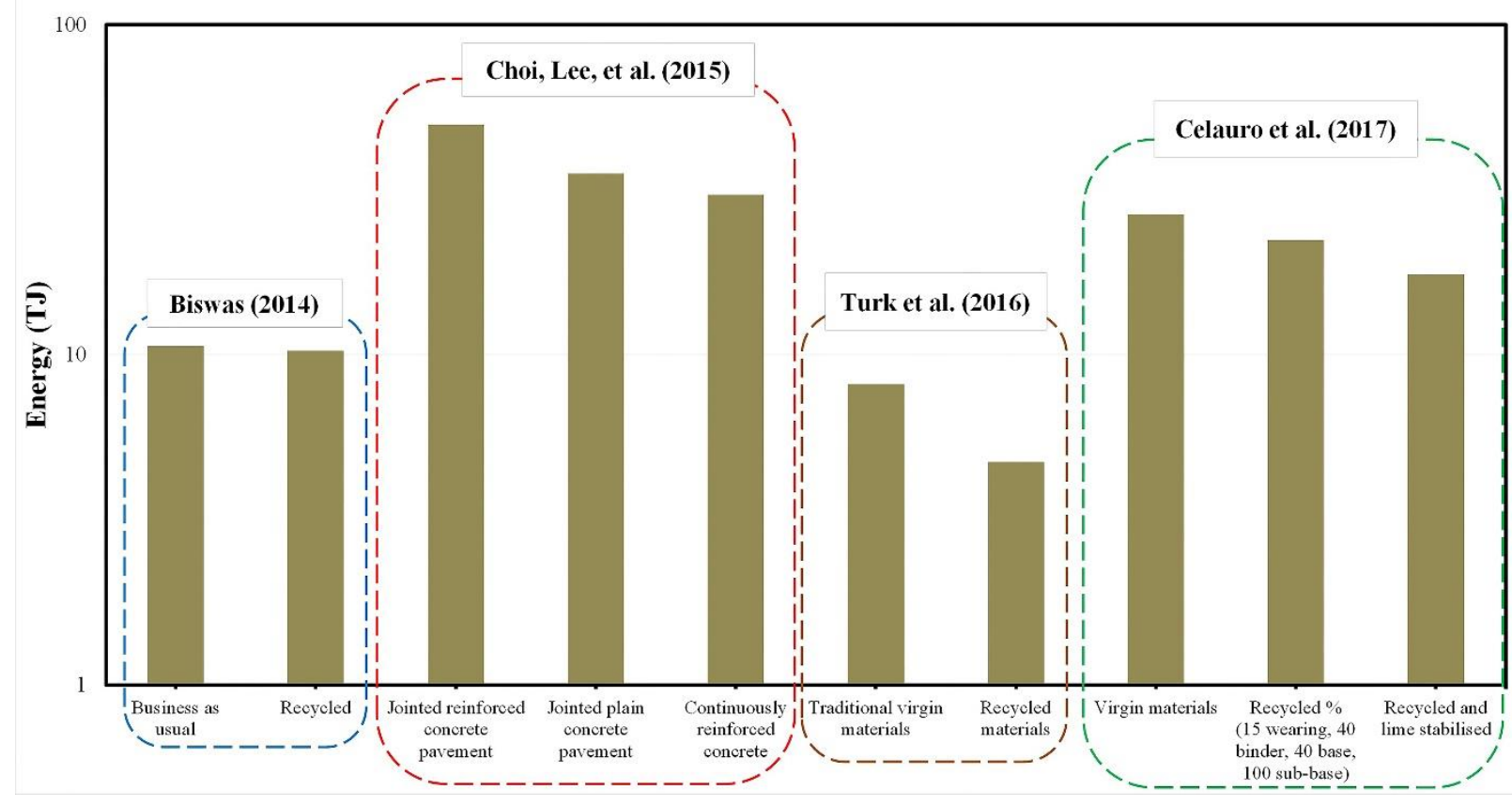

Figure 4 Life-cycle energy burdens of roadways (log scale)

Figure 4 and Figure 5 incorporate a recent study by Turk et al. (2016) which found the use of recycled material as a decreasing factor in energy consumption (by $3.4 \mathrm{TJ}$ ) and global warming potential (by 20 tonnes of CDE). The potential is further realised in the later study by Celauro et al. (2017), where different options with a gradually increased replacement of virgin materials by the recycled options demonstrated improved performance in energy usage (Figure 4) and carbon load (Figure 5) categories. 


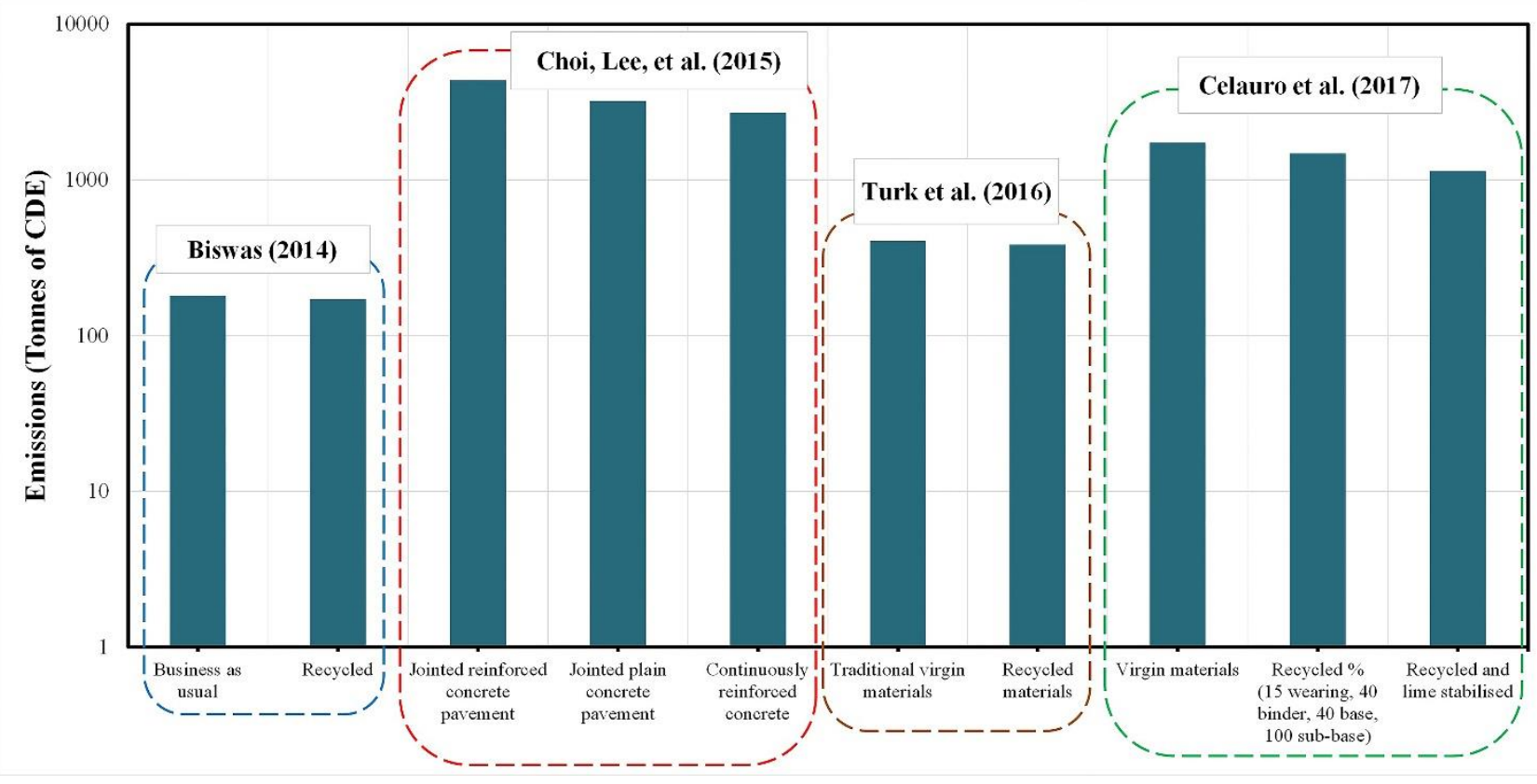

Figure 5 Life-cycle global warming potential of roadway (log scale)

\subsection{Applying LCA in construction, usage, maintenance and rehabilitation stages emissions}

Past trends in developed countries such as the United States have exhibited around 17\% increase (EPA, 2016) in transportation sector GHG emissions in the year 2014 compared to the 1990 appraisals. The EPA (2016) study found the transportation sector as the second highest polluter in the USA. Similar results have been estimated for developing countries (Sadri et al., 2014; Dang and Sui Pheng, 2015) as well as G8 and European countries (Andersen et al., 2013). The operation of road networks and respective fossil fuel consumption costs escalate the financial and environmental impacts from the relatively lower early stage burdens, making roads a hot topic in green infrastructure initiatives. Several factors contribute to the energy consumption and waste emissions associated with the operation of road networks.

Usage stage impacts to road users and mass mobility implications of any early stage decisions as well as the larger system-wide effects, critical to end-consumers, need to be addressed. This aspect is specifically significant for the real-world success of any LCA-based endeavour for high traffic volume roads as the construction and OM\&R activities have been noted to account for less than 5\% of the consumed energy during the whole-life of a road network, whereas the usage stage traffic volume can account for more than 95\% (EAPA/Eurobitume, 2004; Araújo et al., 2014). The study by Araújo et al. (2014) on use of recycled materials in pavement construction, operation and maintenance noted that depending upon traffic volume, the GHG emissions due to traffic operating on the roads are 1000 times larger, with energy consumption 700 times higher, during usage stage compared to the construction stage. This alone intensifies the importance of accounting for the usage stage in LCAs. However, it should be noted that this dominance of usage stage impacts in the LCA results is influenced by the traffic volumes supported by the road. For example, in the study by Santos et al. (2015) comparing low (AADT 300) and high (AADT 2000) traffic volumes, usage stage only accounted 
for $10-21 \%$ of the emissions, whereas material choice and construction methodology dominated the life-cycle impacts of the studied pavements.

In addition, in-place recycling of pavement material may further increase the environmental benefits during construction and rehabilitation stages. Turk et al. (2016) have found that cold in-place recycling can reduce the acidification load by $18 \%$ and energy consumption by $16 \%$ during pavement construction and maintenance on a high traffic (AADT 2500) Slovenia road without significantly compromising on the service life. Recycling construction waste as road aggregates have gained popularity (Hasan, 2015). However, the mechanical properties and stability of roads constructed with recycled materials could be of concern to the different stakeholders because of its status as fit-for-purpose (Hasan et al., 2016b). The technical performance of using recycled materials as pavement base layer was analysed in another study on low traffic volume roads by LopezUceda et al. (2018) with recycled pavement aggregates and Portland cement-fly ash binder mix. They found that the mixed recycled aggregate base exhibited 2.5 MPa tensile strength and $20 \mathrm{MPa}$ compressive strength and may only be suitable for constructing roads with heavy vehicle AADT $<50$. Moisture resistance, fatigue, rutting and stiffness of pavements constructed or rehabilitated with recycled materials was studied by DinisAlmeida et al. (2016) and (Pasandín and Pérez, 2017). They found that even though recycled aggregates increase the absorptive behaviour (demanding more bitumen content), the mixtures exhibited adequate tensile strength, fatigue resistance and moisture resistant similar to the virgin material sample, even for warm-mix asphalt pavements. Furthermore, Miliutenko et al. (2013) note that hot in-place recycled can be applied for low-heavy traffic road types and showed additional $3 \mathrm{GJ}$ equivalent/tonne and 0.02 tonne $\mathrm{CDE}$ of asphalt waste savings compared to in-plant recycling.

\subsection{Frameworks and critical attributes for $L C A$}

Researchers utilising different LCA frameworks have identified contributors like the construction material used, traffic volume and delays, quality of pavement or road design among others over the entire life-cycle of any road network project. Compared to the infancy of LCA and the uncertainties in its functional units, boundary and inventories, LCCA has been widely researched and, often, been a part of roadworks and pavement policymaking under various regulatory agency guidelines (Rangaraju et al., 2008). Integrating LCCA tools within the LCA toolbox can aid decision-makers further by assigning an economic perspective along the environmental context, bringing the question of resource and energy conservation into the picture of cost benefit, thus combining two dimensions of sustainability.

A review by AzariJafari et al. (2016) recognised the diversity of the alternates available to the decisionmakers assessing investment incentives from pavement projects. Inconsistency of LCA frameworks, applied across several components of the larger transit system as well as different stages of the pavements themselves were noted. However, an integrated LCA modelling approach to handle the broader life-span of the projects can still yield value-added future-proofing results. Reviews are often specifically aimed at addressing research challenges, with less emphasis on the real-world case studies; yet, this state-of-the-art review notes that work 
completed highlights the inconsistent selection of functional units and life-cycle stages in different research as among the primary challenges for future wider research or any eventual industry application. Sensitivity of LCA recommendations to the material choices and construction strategies, environmental burdens arising later in the road project's life-cycle (e.g., lighting requirements, carbonation and albedo) were also credited to the type of material used during construction and rehabilitation. Depending upon the system boundary definition, noise is also sometimes included among the environmental burdens (Sánchez et al., 2018). Conversely, other researchers (Oltean-Dumbrava et al., 2013) have instead included in road LCA studies as part of the social indicators.

Furthermore, the source and quality of LCA data (as well as the consistency, transparency and flexibility of applying the LCA recommendations to different design alternatives for diversified road network projects) may also influence the adoption rate of the LCA frameworks by the decision-makers. Table 2 below summarises this work's LCA roads secondary research and provides key variables' weightings thus far. 
Table 2 Scope and methodology of selected LCA-based studies on road network projects

\begin{tabular}{|c|c|c|c|c|c|}
\hline $\begin{array}{l}\text { Study } \\
\text { reference }\end{array}$ & $\begin{array}{l}\text { Roadway } \\
\text { element } \\
\text { typology }\end{array}$ & Functional unit & System boundary & Scenarios analysed & LCI database and resources \\
\hline $\begin{array}{l}\text { Moretti et } \\
\text { al. (2018) }\end{array}$ & $\begin{array}{l}\text { Asphalt } \\
\text { concrete road }\end{array}$ & $\begin{array}{l}3.75 \mathrm{~m} \text { wide dual } \\
\text { lane, } 1 \mathrm{~m} \times 4 \mathrm{~m} \\
\text { cross-section, } 1.5 \\
\mathrm{~m} \text { wide shoulders }\end{array}$ & $\begin{array}{l}\text { - Raw material extraction } \\
\text { - Production and processing } \\
\text { - Construction }\end{array}$ & $\begin{array}{l}\text { Trench vs. embankment road sections. } \\
30-100 \mathbf{~ k m} \text { transportation distances. }\end{array}$ & $\begin{array}{l}\text { - Material transportation: European Commission (2012) } \\
\text { and European Commission (2014). } \\
\text { - Asphalt concrete production: Moretti et al. (2017). } \\
\text { - Cement production: Associazione Italiana Tecnico } \\
\text { Economica Cemento (2016). } \\
\text { - Bitumen and fuel: Eurobitume (2011). } \\
\text { - Aggregates: Officina dell'Ambiente (2013) and Union } \\
\text { Nationale des Producteurs de Granulats (2012). }\end{array}$ \\
\hline $\begin{array}{l}\text { Bloom et al. } \\
\text { (2017) }\end{array}$ & $\begin{array}{l}\text { Urban } \\
\text { highway re- } \\
\text { construction }\end{array}$ & $2.4 \mathrm{~km}$ & $\begin{array}{l}\text { - Raw material extraction } \\
\text { - Production and processing } \\
\text { - Construction }\end{array}$ & $\begin{array}{l}\text { Recycled materials: concrete } \\
\text { aggregates; asphalt pavement (base } \\
\text { course and hot-mix asphalt); asphalt } \\
\text { shingles (partially replacing binder); } \\
\text { blast furnace slag and fly ash (partially } \\
\text { replacing Portland cement). }\end{array}$ & $\begin{array}{l}\text { - Quantity take-offs: Local agencies and design plans. } \\
\text { - Environmental impacts: Compared outputs from two } \\
\text { emissions modelling software; PaLATE (option 1) and } \\
\text { SimaPro (option 2). }\end{array}$ \\
\hline $\begin{array}{l}\text { Celauro et } \\
\text { al. (2017) }\end{array}$ & $\begin{array}{l}\text { Asphalt } \\
\text { pavement } \\
\text { (urban road) }\end{array}$ & $\begin{array}{l}1 \mathrm{~km} \text {, single } \\
\text { carriageway. } \\
30 \text { years analysis } \\
\text { period }\end{array}$ & $\begin{array}{l}\text { - Production and processing } \\
\text { - Construction } \\
\text { - Maintenance and } \\
\text { rehabilitation }\end{array}$ & $\begin{array}{l}\text { Five scenarios varying: virgin, } \\
\text { recycled and lime stabilised materials. } \\
\text { Maintenance plans: repaving wearing } \\
\text { course vs. maintenance of all courses. }\end{array}$ & $\begin{array}{l}\text { - Unit materials: Regional Council Office for } \\
\text { Infrastructure and Mobility (2013). } \\
\text { - Emissions calculation: Local resources and PaLATE. }\end{array}$ \\
\hline $\begin{array}{l}\text { Chen et al. } \\
(2017)\end{array}$ & $\begin{array}{l}\text { Cement and } \\
\text { asphalt roads }\end{array}$ & $\begin{array}{l}\text { No specifically } \\
\text { defined }\end{array}$ & $\begin{array}{l}\text { - Raw material extraction } \\
\text { - Production and processing } \\
\text { - Construction }\end{array}$ & Low to high volume traffic roads & $\begin{array}{l}\text { - Minerals, aggregate and asphalt GHG emissions: } \\
\text { Zhang and Liu (2015) and Wang and Wei (2015). } \\
\text { - GHG factors: Regional data and Zhao et al. (2016) }\end{array}$ \\
\hline $\begin{array}{l}\text { Karlsson et } \\
\text { al. }(2017)\end{array}$ & $\begin{array}{l}\text { Urban road } \\
\text { re- } \\
\text { construction }\end{array}$ & $7.5 \mathrm{~km}$ 3-lane road & $\begin{array}{l}\text { - Construction } \\
\text { - Maintenance and } \\
\text { rehabilitation }\end{array}$ & $\begin{array}{l}\text { Two alternatives: reconstruction of } \\
\text { entire road } v \text { s. only reconstructing } \\
\text { end and start. }\end{array}$ & $\begin{array}{l}\text { - GHG emissions and energy use: Goedkoop et al. } \\
\text { (2009), Lundberg et al. (2013) and Toller et al. (2014). } \\
\text { - Material and other environmental factors: Stripple } \\
\text { (2001) and other local resources. }\end{array}$ \\
\hline
\end{tabular}


$1 \mathrm{~km}, 3.5 \mathrm{~m}$ lane construction and maintenance (after 15 years). life span Butt et al. Asphalt road
(2016)

Turk et al. (2016)

\section{Anastasiou Urban}

et al. (2015) concrete pavement with asphalt overlay

\section{Choi et al.}

(2015b)

$\begin{array}{ll}\text { Rigid } & 1 \mathrm{~km} \text { long \& } \\ \text { highway } & 14.8 \mathrm{~m} \text { wide. } 50 \\ \text { pavement } & \text { years life span } \\ \text { rehabilitation } & \end{array}$

Santos et al. Typical (2015) Portuguese flexible pavement $1 \mathrm{~km}, 4 \mathrm{~m}$ wide.

20 years design life

40,000 sq. m pavement of road serving 2500 AADT
$1 \mathrm{~km}$ of 4 main

(3.75 m) lanes \& outer, inner shoulders (3 m, $1.5 \mathrm{~m}) .40$ years analysis period
- Production and processing

- Construction

- Maintenance and

rehabilitation

7.3 wide dual lane - Raw material extraction low traffic $1 \mathrm{~km} \quad$ - Production and processing road and 40 years' - Construction

- Maintenance and

rehabilitation

- End-of-life

- Production and processing

- Construction

- Maintenance and

rehabilitation

- End-of-life

- Raw material extraction

- Production and processing

- Construction

- Maintenance and

rehabilitation

- Operation and usage

- End-of-life
Four scenarios: Two unmodified asphalt mix aggregates $v s$. adding warm mix asphalt.

Two case studies with different pavement cross-sections.

Traditional virgin materials $\boldsymbol{v s}$. recycled (stabilised asphalt concrete) materials.

Various scenarios comparing different percentages of recycled and virgin materials.

Compared pavement types; continuously reinforced concrete $(30$ years' service) $v \boldsymbol{s}$. jointed plain concrete (20 years' service) vs. jointed reinforced concrete ( 15 years' service).

Two classes of AADT, 16 types of hot- - Electricity, coal and crude oil: Dones et al. (2007). mix asphalt and asphalt concrete pavement structures and the $\mathbf{3}$ foundation types from the Portuguese pavement design catalogue.

- On-road vehicles, construction equipment and material transport: EEA (2009).

- Production of HMA: US EPA (2004).

- Aggregates: Jullien et al. (2012).

- Bitumen and bituminous emulsion: Eurobitume (2011).
- GHG emissions: Local resources, EAPA/Eurobitume (2004) and Klöpffer (2006).

- Energy consumption: ECRPD (2010), Sheehan et al. (1998) and Stripple (2001).

- Asphalt production energy use: Local contractors.

- Fuel, electricity mix and other material consumption data: Stripple (2001)

- Fossil fuel, asphalt binder, virgin aggregates, recycled stabiliser and material transport: GaBi 4.0 database.

Portland cement dataset: Josa et al. (2004), EPD

(2012), EPD (2015) and Ammenberg et al. (2015).

- Material consumption: Marceau et al. (2007) and Eurobitume (2011).

- Greenhouse gas emissions: IPCC (2008)

- Unit cost data collected and miscellaneous data sources through Carnegie Mellon University (2011). 
Yu and Lu Overlay

(2014) pavement section

$\mathrm{Yu}$ and $\mathrm{Lu}$ Rehabilitation $1 \mathrm{~km}$ overlay. 40

(2012) of Portland year service life

cement

concrete

pavement

Wang et al. Rehabilitation Not explicitly

(2012)

of rural road

segments

defined as

compared rolling

resistance effect

for different case

studies

\begin{tabular}{lll}
$\begin{array}{l}\text { Cass and } \\
\text { Mukherjee } \\
(2011)\end{array}$ & $\begin{array}{l}\text { Highway } \\
\text { concrete } \\
\text { pavement } \\
\text { rehabilitation }\end{array}$ & $\begin{array}{l}\text { Per lane mile of } \\
\mathrm{CO}_{2} \text { equivalent }\end{array}$ \\
$\begin{array}{l}\text { Lee et al. } \\
(2010)\end{array}$ & $\begin{array}{l}\text { Asphalt } \\
\text { highway road } \\
\text { surface }\end{array}$ & $\begin{array}{l}4.7 \mathrm{~km} \text { long } \\
\text { section }\end{array}$ \\
\hline
\end{tabular}

- Raw material extraction

- Production and processing

- Construction

- Maintenance and

rehabilitation

- Raw material extraction Five bridge design options.

- Production and processing

- Construction

- End-of-life

- Pavement albedo during operation and usage

- Raw material extraction

- Production and processing

- Construction

- Operation and usage

- End-of-life

- Raw material extraction $\quad \mathbf{3 4 , 0 0 0}$ AADT (2-lanes) vs. 3,200

- Production and processing AADT (4-lanes) asphalt roads with

- Construction

- Operation and usage

capital preventive maintenance strategies; vs. 86,000 AADT (2-lanes) vs. 11,200 AADT (2-lanes) concrete restoration.

Two modelling approaches; with and without SimaPro in the emissions

- Equipment manufacture

- Raw material extraction

- Production and processing calculations.

- Construction roads with concrete pavement

- Limestone and hot-mix bitumen: Whyte (2015b). - Equipment and energy data: RMIT (2007) database. - Recycled concrete and crushed rock base: Mitchell (2012) and RMCG (2010).

- Material and quantity data: local contractors.

- Environmental inventory data: From Ecoinvent v2.2 public database for the local conditions.

Portland cement concrete vs. hot-mix - Based on empirical relations proposed by Bird et al (2008), Muñoz et al. (2010) and Susca (2012).

- Material consumption: Marceau et al. (2007), Stripple (2001) and Meil (2006).

- Transportation of materials: Wang (2011).

- Construction equipment: EPA NONROAD 2008 model.

- Fuel consumption: EPA (2005) and Amos (2006).

- Cements, aggregates and concrete: Stripple (2001), Meil (2006), Dones et al. (2007) \& Marceau et al. (2007). - HMA and rubberised hot-mix asphalt: Stripple (2001) and Meil (2006) and USLCI database by NREL (2011). - Oil manufacturing and feedstock: Dones et al. (2007).

- Material and equipment inventories: Field data using Info Tech. Inc.'s Field Manager® software.

- Emissions: SimaPro 7 and e-Calc emissions calculator.

- Raw material extraction Traditional AASHTO pavement design - Emissions and inventory: PaLATE and EPA (2009).

- Production and processing

- Construction 
The potential for uptake of a (newly) developed LCA framework based upon the real world studies tabulated above (Table 2) is particularly important for advocating the practicable usage of sustainable approaches such as the use of recycled materials for construction and maintenance of road network projects. Research has shown that utilising recycled and waste material for road construction reduces environmental impacts, landfill pressure and extraction costs but that, negative perception by stakeholders, regarding poor performance of such materials and high cost, hinder large-scale practical application (Huang et al., 2007). The critical review study by Wang et al. (2018) attempted to provide extensive coverage and summary of significant findings in the current recycling technologies for road network projects. Several of the tabulated authors above claim that the recycled material inclusion during construction and maintenance activities remains promising for reducing energy load and GHG emissions compared to use of virgin materials.

Leachate generated from constructed road base using recycled techniques and feedstock energies were minimal when paralleled with overall life-cycle benefits. However, recycling techniques such as terminal blend, dry and wet rubberised and recycled asphalt mixing; and, use of slag and fly ash as pavement stabilisers were often deemed critical to meet the cost and environmental goals of municipal authorities. In addition, the cost performance and variation in the environmental impacts from use of recycled materials during the entire life-cycle, particularly the usage stage need to be identified. More studies based on real-world data and problem handling for actual road network and transit system projects are helpful for government and public stakeholders to correctly visualise the benefits of recycled materials. Necessarily, it raises the question of accurately comparing the various mixing techniques, materials, recycling ratios and construction strategies across different alternatives.

This state-of-the-art analysis of past research via the document-analysis, secondary research approach presented goes towards developing a LCCA/LCA framework to aid the decision-making process. The selected pool of key literature has been reviewed in Table 2 to reflect the critical aspects of LCA methodology, use of recycled and alternate materials and establishment of LCA inventories. The crucial recycling techniques and data resources that may be useful to any future studies or industry applications are summarised in the above table. Comparison of functional units and system boundaries complimented by the required datasets is also provided to aid the decision-makers, project planners and managers and various public and private actors interested in the sustainable design and management of road networks.

\subsection{Summary and gaps from the reviewed LCA frameworks}

The studies presented in Table 2 attempted to analyse the (cost and) environmental load reduction performance of the strategies adopted by the local authorities for the construction and management of road networks. For the application of any LCA frameworks in road network projects, specifically to 
move further towards real-world use, the following paragraphs aim to recapitulate the current state of research and provide suggestions.

- A general lack of dynamic user traffic patterns and "consumer" impact assessment are argued here to represent serious constraints to future application(s) of LCA frameworks. Likewise, very few research papers attempted to integrate the system-wide impacts across all the life-cycle stages, which is argued here as needed due to the considerably long-term usability of road networks. Unless proper integration can be achieved in the framework and reasoning behind indicator, functional unit and system boundary selection, becomes more transparent, LCA recommendations of project alternatives remain open to subjective interpretation which can deter uptake.

- Selective analysis of life-cycle stages occurred inherently in a majority of studies albeit only one study (Santos et al., 2015) considered feedback loops, energy and GHG feeds from the entire road life-cycle. Recycling or end-of-life was the second most neglected stage; only three studies included environmental load from this stage. Frequent maintenance and rehabilitation schedules of the deteriorating road surfaces was addressed by four studies, while extraction of raw materials was added to the framework parameters in nine studies. Production and processing benefits of recycled against virgin materials were examined in eleven studies and construction stage(s) was considered by all of the studies except the pavement albedo study where it was out of the research scope. Nowadays, real-world scenario representations and improvements of stakeholder confidence in LCA frameworks, require that parameters from all stages of the road network life-cycle are needed to capture the magnitude of cost and environmental benefits of recycling.

- For comprehensive LCA framework considering all stages (Santos et al., 2015), a majority of the data was either assumed based on existing literature or calculated from an amalgamation of regional and foreign unit costs, emissions and energy feed datasets. Regarding the foreign datasets, significant research is available along with calculators from European and US-based resources, which may be applicable to other regions. However, this may produce methodological challenge in the applicability and sensitivity of results.

- Shortages of local and actual case and region-specific data resources for some regions around the world hinder the application of LCA frameworks in both research and industry projects as majority of the existing datasets and life-cycle frameworks are developed from US and European case studies and the difference between the system advancements, production/construction laws, norms and regulations and technical process are varied between regions (Santos et al., 2017). However, this may be resolved by collecting local LCI resources and comparing the data flexibility of existing studies for missing datasets to deduce how they (in isolation or collectively) can be applied to handle the missing data.

- Asphalt recyclability is arguably one of the most significant findings of most studies leading to loss of stored feedstock energy with wear and tear. Repaving or on-site recycling of asphalt rephrases 
the asphalt vs. concrete recyclability archetype analysis due to the difference in perceived usability as sub-base for the new road constructed over the completely deteriorated structure.

- Energy feeds, cost and emissions from transferal waste resources such as blast furnace slag and fly ash to partially replace cement binders in concrete or asphalt-concrete pavements are argued here as key aspects. Some researchers (Silva et al., 2015; Hoy et al., 2017) suggest that recycling and reuse of materials may result in some strength loss due to aging, such that extracted recycled materials required to be stabilised by industrial wastes (Hasan et al., 2015). It is argued here that any future developed LCA frameworks should acknowledge positive mapping of transferred waste reuse credits, and require explicit recognition that recycling waste outputs divert away from landfilling sites.

\subsection{Normalisation and weighting for LCA interpretation}

Due to the diversity in material choices available for road construction, ranging from virgin materials (asphalt and concrete), mixing technique (hot, warm and cold); several environmental impacts of varying magnitudes and units are generated across the different life-cycle stages. For example, climate change is generally expressed as " $\mathrm{kg} \mathrm{CO}$ equivalent", whereas acidification is expressed as " $\mathrm{kg}$ $\mathrm{SO}_{2}$ equivalent" and normalisation provides a common reference point (Stranddorf et al., 2005) for planners. The normalisation values that are used for interpreting the LCIA results for the different geographical regions around the world are presented in Table 3, as a concise reference point for future works. The values and units are based upon the data from the updated ReCiPe model.

Table 3 Annual normalisation factors for some environmental impact categories (adapted from Bengtsson and Howard (2010) and Huijbregts et al. (2017))

\begin{tabular}{|c|c|c|c|}
\hline \multirow{2}{*}{ Environmental impact categories (unit) } & \multicolumn{3}{|c|}{ Normalisation Factors } \\
\hline & Global & Europe & Australia \\
\hline Climate change ( $\mathrm{kgCO}_{2}$ equivalent/year $)$ & $3.36 \times 10^{13}$ & $4.49 \times 10^{12}$ & $6.21 \times 10^{11}$ \\
\hline Ozone depletion ( $\mathrm{kg} C \mathrm{CFC}$-11 equivalent/year) & $2.29 \times 10^{8}$ & $1.02 \times 10^{7}$ & $4.17 \times 10^{4}$ \\
\hline Fossil fuel depletion ( $k g$ of oil equivalent/year) & $7.84 \times 10^{12}$ & $7.23 \times 10^{11}$ & - \\
\hline Acidification $\left(\mathrm{kgSO}_{2}\right.$ equivalent/year $)$ & $2.56 \times 10^{11}$ & $1.79 \times 10^{10}$ & $2.67 \times 10^{9}$ \\
\hline Terrestrial eco-toxicity ( $k g$ 1,4-DB equivalent/year) & $4.96 \times 10^{10}$ & $6.50 \times 10^{9}$ & $1.90 \times 10^{9}$ \\
\hline Freshwater eco-toxicity ( $\mathrm{kg}$ 1,4-DB equivalent/year) & $2.77 \times 10^{10}$ & $5.43 \times 10^{9}$ & $3.71 \times 10^{9}$ \\
\hline Marine eco-toxicity ( $k g$ 1,4-DB equivalent/year) & $4.11 \times 10^{12}$ & $1.18 \times 10^{12}$ & $2.62 \times 10^{14}$ \\
\hline
\end{tabular}


Human toxicity ( $k g$ 1,4-DB equivalent/year)

Eutrophication ( $k g$ P equivalent/year)

Particulate matter (kg PM equivalent/year)

Photochemical oxidation ( $k g$ NMVOC equivalent/year)

$\begin{array}{lll}8.83 \times 10^{12} & 2.08 \times 10^{12} & 6.96 \times 10^{10} \\ 1.76 \times 10^{9} & 1.93 \times 10^{8} & 1.39 \times 10^{8} \\ 8.55 \times 10^{10} & 6.93 \times 10^{9} & 9.82 \times 10^{8} \\ 3.45 \times 10^{11} & 2.64 \times 10^{10} & 1.61 \times 10^{9}\end{array}$

It may be further argued that the current environmental objectives of the country may assess the environmental consequences of the construction decision differently due to perceived importance of each impact category and may prefer assigning scores or weightings, based on expert opinions. For example, some of the environmental categories occurring during the life-cycle stages of a road project are illustrated below in Figure 6 (Bengtsson et al., 2010). Compared to the normalisation factors, the weighting values are highly dependent upon the specific objectives of a regional agency, sociodemographics of the expert panel used for assigning the weighting values and the sampling size. In general, impact weighting generation and prioritisation uses the methods available for multi-criteria decision-making (MCDM) such as analytic hierarchy process (AHP) and fuzzy rankings.

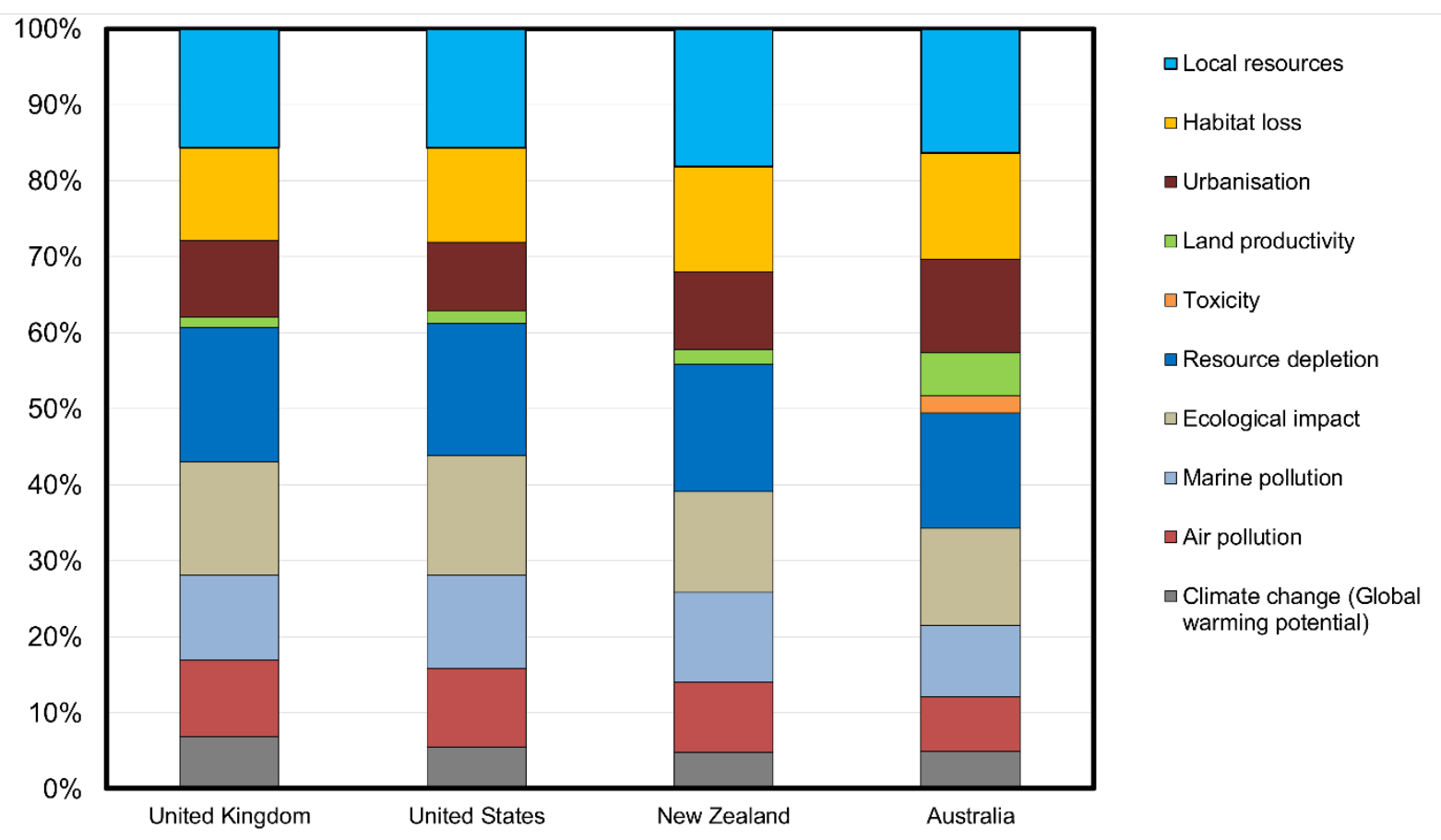

Figure 6 The average weighting factors for some of the life-cycle impact categories (adapted from Lippiatt (2007), Bengtsson et al. (2010) and Abbe and Hamilton (2017))

\section{Requirements, needs and demands: summarising the social component}

Growth in population inherently requires residents' mobility and accessibility within a city that is serviced by its extensive road networks. Traditionally these road networks are designed to facilitate 
rapid personal travel and are built around private automobile transit. For example, Chester et al. (2010) have stated that the infrastructure in most cities in the United States is centred on automobile travel. As urban road networks mature, agencies are forced to seek a trade-off between high maintenance of existing facilities versus road network expansion costs due to increased usage. Indeed Chester et al. (2010) further propose developing growth models based on historical data to highlight the transferal occurrences where investment focus of urban agencies shifts to maintaining existing road networks from constructing new and alternate strategies extrapolated from present usage. The limited maintenance funds of municipal agencies are stretched by the elevated road network deteriorations due to traffic congestion and pavement surface wear and tear. This inhibits the functionality, durability and ability of road networks as the maximum benefit provider to the users. Linear combinations of all cost and environmental components across the modules of the road network projects need to be balanced against the user mobility and benefit to commuters.

Transport agencies encourage modal shift towards public transport to reduce private automobile travel and increase the functionality and benefit-provision performance of road networks (Gray et al., 2016). In order to achieve this, the municipal transport agencies should focus upon perceiving transit as a competitive service that provides users with a quality service, supported by efficient road networks. Amirgholy et al. (2017) noted that, similar to any consumer product, a quality public transport service and supporting road network comes at high capital and environmental cost to the management public authority agency. Any future study on life-cycle management of road network projects must then evaluate the supported transit and related mobility modules as a marketing and consumer behavioural problem. In this way, a dynamic LCCA/LCA package integrating user needs, mobility trends, road network projects and mass-transit, can aggregate multi-level cost, energy and environmental flows. Thus not only will such a tool indicate increases in the functionality and user adoption of the project alternatives proposed by the municipal agencies, but also make the sustainable design and management of road network projects conceivable to the decision-makers, project planners and other stakeholders.

\section{Conclusions and future research directions}

Due to the limited capital funds available to municipal authorities and the higher effect of cost uncertainties on profit compared to environmental performance, the importance of cost parameters requires highlighting during decision-making. The diversity of initial cost optimisation literature in the earliest reported studies on road network project assessment is a testament to the relative importance of initial cost. Since the 1970s, whole-life approaches to optimise cost over the entire project life has been extensively discussed and several LCCA frameworks and attributes have been proposed.

This state of the art review paper summarised the existing literature attributes to overcome the issue of real-world adoption and subsequently links and consistency with the respective environmental analyses. National and international interest on reducing environmental burdens and energy input loads 
of construction projects has generated LCA tools as a knowledge quantification toolbox. LCA has been used in a number of road network projects to examine and enhance the cost and environmental futureproofing performance of design, operation, maintenance and recycling decisions. Due to this reason, both cost and environmental frameworks have been reviewed in this study recognising that in the future LCCA frameworks must be embedded in the more holistic LCA frameworks.

The current review study examined 36 (extensively) and 97 (supporting) life-cycle cost, and environmental articles, from peer-review journals targeting research on design, management and recycling of actual real-life road network assets. The findings show that:

1. The interest of stakeholders and researchers in "sustainable" road and transit has increased in recent years. However, a majority of studies were conducted in limited geographical contexts (USA and European) or constrained focus to only a few stages of the road network life-cycle. Regarding the cost component, several attributes have been proposed by research to achieve cost optimisation of road network projects through LCCA-based comparison of design alternatives (refer to Section 2.6).

2. User and embedded social costs of road network projects are significantly higher than the initial capital investments and should be given preference (Figure 3 results above). User adoption, dynamic traffic growth patterns, future cash-flows and user-accorded benefits should be targeted to present the local authority transport planners with the opportunity of reducing the analysis uncertainties due to decision-maker and user prejudice. The challenges and future research directions are elaborated in Section 2.7.

3. The time period of analysis examining life-cycle burdens of different project alternatives for road networks and the highly subjective nature of the somewhat intangible benefits obtained as a result of investments, no matter how difficult to quantify with a deterministic approach, must also be incorporated and measured explicitly.

4. The use of recycled and industrial waste materials has demonstrated a potential in increasing cost performance, environmental benefits and resource savings compared to use of virgin materials, mechanical and fit-for-purpose performance of pavements build with recycled materials should also be investigated for the traffic, distress and fatigue levels.

5. A side-benefit of utilising recycled and waste materials in road projects is preventing groundwater contamination and leachate generation in the aquifers located close to landfills, particularly in developing countries.

6. The GHG emissions from construction design alternatives of road network projects utilising recycled materials was comparatively less than virgin materials' utilisation, for example, (Celauro et al., 2017) revealed a maximum of 34.5\% CDE reduction (as Figure 5 in Section 3.3). 
7. Resource and energy loads of pavements constructed by material mixes containing lime-stabilised and recycled materials (Celauro et al., 2017) was $34.21 \%$ or $3.1 \mathrm{TJ}$ lower than virgin materials alternatives as shown in Figure 4 of Section 3.3.

8. The LCIA results may be presented in a more comprehensible form using normalisation factors and expert-assigned weighting scores in the interpretation phase. Stakeholder interest can be addressed through meeting user needs, agency objectives and proper stakeholder engagement through the incorporation of the social component into LCA tools (as discussed in Section 4).

The eight items above represent the way forward for a real-world application of life-cycle analysis in road network projects.

\section{Acknowledgement}

This research project is supported by an Australian Government Research Training Program (RTP) scholarship.

\section{References}

Abbe, O., Hamilton, L., 2017. BRE global environmental weighting for construction products using selected parameters from EN15804. BRE Global Ltd., Hertfordshire, UK.

Agency, E.E., 2009. EMEP/EEA air pollutant emission inventory guidebook-2009, Technical guidance to prepare national emission inventories. Publications Office of the European Union, Luxembourg.

Agency, U.S.E.P., 2004. AP-42: Compilation of Air Pollutant Emission Factors: Preliminary Document. Environmental Protection Agency.

Alqahtani, A., Whyte, A., 2013. Artificial neural networks incorporating cost significant Items towards enhancing estimation for (life-cycle) costing of construction projects. Construction Economics and Building 13(3), 51-64.

Alqahtani, A., Whyte, A., 2016. Evaluation of non-cost factors affecting the life cycle cost: an exploratory study. Journal of Engineering, Design and Technology 14(4), 818-834.

American Standard for Testing of Materials (ASTM), 2015. Standard Practice for Measuring LifeCycle Costs of Buildings and Building Systems. ASTM International, West Conshohocken, PA, p. 23.

Amirgholy, M., Shahabi, M., Gao, H.O., 2017. Optimal design of sustainable transit systems in congested urban networks: A macroscopic approach. Transportation Research Part E: Logistics and Transportation Review 103, 261-285.

Ammenberg, J., Baas, L., Eklund, M., Feiz, R., Helgstrand, A., Marshall, R., 2015. Improving the $\mathrm{CO} 2$ performance of cement, part III: the relevance of industrial symbiosis and how to measure its impact. Journal of Cleaner Production 98, 145-155.

Amos, D., 2006. Pavement smoothness and fuel efficiency: an analysis of the economic dimensions of the Missouri Smooth Road Initiative. Missouri Department of Transportation, Missouri, USA, p. 28. 
Anastasiou, E.K., Liapis, A., Papayianni, I., 2015. Comparative life cycle assessment of concrete road pavements using industrial by-products as alternative materials. Resources, Conservation and Recycling 101, 1-8.

Andersen, O., Jensen, C.S., Torp, K., Yang, B., 2013. EcoTour: reducing the environmental footprint of vehicles using eco-routes, IEEE 14th International Conference on Mobile Data Management (MDM). IEEE, Milan, Italy, pp. 338-340.

Anthonissen, J., Van den bergh, W., Braet, J., 2016. Review and environmental impact assessment of green technologies for base courses in bituminous pavements. Environmental Impact Assessment Review 60, 139-147.

Araújo, J.P.C., Oliveira, J.R., Silva, H.M., 2014. The importance of the use phase on the LCA of environmentally friendly solutions for asphalt road pavements. Transportation Research Part D: Transport and Environment 32, 97-110.

Associazione Italiana Tecnico Economica Cemento, 2016. Environmental Product Declaration: Average Italian Cement. Rome, Italy, p. 18.

AzariJafari, H., Yahia, A., Ben Amor, M., 2016. Life cycle assessment of pavements: reviewing research challenges and opportunities. Journal of Cleaner Production 112, 2187-2197.

Babashamsi, P., Md Yusoff, N.I., Ceylan, H., Md Nor, N.G., Salarzadeh Jenatabadi, H., 2016. Evaluation of pavement life cycle cost analysis: Review and analysis. International Journal of Pavement Research and Technology 9(4), 241-254.

Baker, M.B., Abendeh, R., Abu-Salem, Z., Khedaywi, T., 2016. Production of Sustainable Asphalt Mixes Using Recycled Polystyrene. International Journal of Applied Environmental Sciences 11(1), 183-192.

Balaguera, A., Carvajal, G.I., Albertí, J., Fullana-i-Palmer, P., 2018. Life cycle assessment of road construction alternative materials: A literature review. Resources, Conservation and Recycling 132, 37 48.

Batouli, M., Bienvenu, M., Mostafavi, A., 2017. Putting sustainability theory into roadway design practice: Implementation of LCA and LCCA analysis for pavement type selection in real world decision making. Transportation Research Part D: Transport and Environment 52, 289-302.

Bengtsson, J., Howard, N., 2010. A Life Cycle Impact Assessment Method - Part 2: Normalisation. Canberra, Australian Capital Territory, p. 41.

Bengtsson, J., Howard, N., Kneppers, B., 2010. Weighting of environmental impacts in Australia. Canberra, Australian Capital Territory, p. 75.

Bird, D.N., Kunda, M., Mayer, A., Schlamadinger, B., Canella, L., Johnston, M., 2008. Incorporating changes in albedo in estimating the climate mitigation benefits of land use change projects. Biogeosciences Discuss. 2008, 1511-1543.

Biswas, W.K., 2014. Carbon footprint and embodied energy assessment of a civil works program in a residential estate of Western Australia. The International Journal of Life Cycle Assessment 19(4), 732-744.

Bloom, E., Canton, A., Ahlman, A.P., Edil, T., 2017. Life Cycle Assessment of Highway Reconstruction: A Case Study, Transportation Research Board 96 ${ }^{\text {th }}$ Annual Meeting. Transportation Research Board, Washington DC, United States, p. 19. 
Butt, A.A., Birgisson, B., 2016. Assessment of the attributes based life cycle assessment framework for road projects. Structure and Infrastructure Engineering 12(9), 1177-1184.

Butt, A.A., Birgisson, B., Kringos, N., 2016. Considering the benefits of asphalt modification using a new technical life cycle assessment framework. Journal of Civil Engineering and Management 22(5), 597-607.

Butt, A.A., Toller, S., Birgisson, B., 2015. Life cycle assessment for the green procurement of roads: a way forward. Journal of Cleaner Production 90, 163-170.

Cabeza, L.F., Rincón, L., Vilariño, V., Pérez, G., Castell, A., 2014. Life cycle assessment (LCA) and life cycle energy analysis (LCEA) of buildings and the building sector: A review. Renewable and Sustainable Energy Reviews 29, 394-416.

Carnegie Mellon University, 2011. EIO-LCA: Free, fast, easy life cycle assessment.

Cass, D., Mukherjee, A., 2011. Calculation of greenhouse gas emissions for highway construction operations by using a hybrid life-cycle assessment approach: case study for pavement operations. Journal of Construction Engineering and Management 137(11), 1015-1025.

Celauro, C., Corriere, F., Guerrieri, M., Lo Casto, B., Rizzo, A., 2017. Environmental analysis of different construction techniques and maintenance activities for a typical local road. Journal of Cleaner Production 142, 3482-3489.

CEN EN 15804, 2013. Sustainability of construction works - Environmental product declarations Core rules for the product category of construction products. European Committee for Standardisation, Brussels, Belgium, p. 65.

Chen, J., Zhao, F., Liu, Z., Ou, X., Hao, H., 2017. Greenhouse gas emissions from road construction in China: A province-level analysis. Journal of Cleaner Production 168, 1039-1047.

Chen, S.-H., Ni, F.M.-W., 2018. Explore pavement roughness under various funding for the Taiwan provincial highways using LCCA. International Journal of Pavement Engineering, 1-8.

Chester, M., Horvath, A., Madanat, S., 2010. Parking infrastructure: Energy, emissions, and automobile life-cycle environmental accounting. Environmental Research Letters 5(3), 034001.

Choi, K., Kim, Y.H., Bae, J., Lee, H.W., 2015a. Determining Future Maintenance Costs of LowVolume Highway Rehabilitation Projects for Incorporation into Life-Cycle Cost Analysis. Journal of Computing in Civil Engineering, 04015055.

Choi, K., Lee, H.W., Mao, Z., Lavy, S., Ryoo, B.Y., 2015b. Environmental, Economic, and Social Implications of Highway Concrete Rehabilitation Alternatives. Journal of Construction Engineering and Management 142(2), 04015079.

Dang, G., Sui Pheng, L., 2015. Infrastructure investments in developing economies: The case of Vietnam, 1 ed. Springer Singapore, Singapore.

Dinis-Almeida, M., Castro-Gomes, J., Sangiorgi, C., Zoorob, S.E., Afonso, M.L., 2016. Performance of Warm Mix Recycled Asphalt containing up to 100\% RAP. Construction and Building Materials 112, 1-6.

Dones, R., Bauer, C., Bolliger, R., Burger, B., Faist Emmenegger, M., Frischknecht, R., Heck, T., Jungbluth, N., Röder, A., Tuchschmid, M., 2007. Life cycle inventories of energy systems: results for 
current systems in Switzerland and other UCTE countries, in: Dones, R. (Ed.). Paul Scherrer Institut Villigen, Dübendorf, Switzerland, p. 176.

Du, G., Safi, M., Pettersson, L., Karoumi, R., 2014. Life cycle assessment as a decision support tool for bridge procurement: environmental impact comparison among five bridge designs. The International Journal of Life Cycle Assessment 19(12), 1948-1964.

EAPA/Eurobitume, 2004. Environmental impacts and fuel efficiency of road pavements. European Asphalt Pavement Association, Brussels, Belgium, p. 22.

ECRPD, 2010. Energy conservation in road pavement design, maintenance and utilisation, Intelligent Energy Europe. European Commission, Waterford, Ireland, p. 63.

EPA, 2005. Emission Facts: Average carbon dioxide emissions resulting from gasoline and diesel fuel. Office of Transportation and Air Quality, Washington, DC.

EPA, 2009. Gasoline and Diesel Industrial Engines-Emission Factor Documentation for AP-42 Section 3.3. US Environmental Protection Agency.

EPA, 2016. Inventory of US greenhouse gas emissions and sinks: 1990-2014. EPA 430-R-11-005.

EPD, 2012. Environmental Product Declaration: CEM IV/B(P)32,5, Çimsa Çimento San. Ve Tic. A.Ş. Institut Bauen und Umwelt (IBU), Berlin, Germany, p. 7.

EPD, 2015. Environmental Product Declaration: Blust Furnace Cement (CEM III) Produced in Europe. European Cement Association, Brussels, Belgium.

Eurobitume, 2011. Life cycle inventory: bitumen (online). Eurobitume.

European Commission, 2012. Commission Regulation (EU) No. 459/2012 of 29 May 2012 Amending Regulation (EC) No. 715/2007 of the European Parliament and of the Council and Commission Regulation (EC) No. 692/2008 as Regards Emissions from Light Passenger and Commercial Vehicles (Euro 6). European Union, Brussels, Belgium.

European Commission, 2014. Strategy for reducing heavy-duty vehicles fuel consumption and $\mathrm{CO}_{2}$ emissions. European Union, Brussels, Belgium.

Fava, J.A., Smerek, A., Heinrich, A.B., Morrison, L., 2014. The Role of the Society of Environmental Toxicology and Chemistry (SETAC) in Life Cycle Assessment (LCA) Development and Application, in: Klöpffer, W. (Ed.) Background and Future Prospects in Life Cycle Assessment. Springer Netherlands, Dordrecht, pp. 39-83.

Fuglestvedt, J., Berntsen, T., Myhre, G., Rypdal, K., Skeie, R.B., 2008. Climate forcing from the transport sectors. Proceedings of the National Academy of Sciences 105(2), 454-458.

Galí, J., 2015. Monetary Policy, Inflation, and the Business Cycle: An Introduction to the New Keynesian Framework and Its Applications, 2nd ed. Princeton University Press, New Jersey, US.

Gautam, P.K., Kalla, P., Jethoo, A.S., Agrawal, R., Singh, H., 2018. Sustainable use of waste in flexible pavement: A review. Construction and Building Materials 180, 239-253.

Giang, D.T.H., Pheng, L.S., 2015. Critical Factors Affecting the Efficient Use of Public Investments in Infrastructure in Vietnam. Journal of Infrastructure Systems 21(3), 05014007. 
Goedkoop, M., Heijungs, R., Huijbregts, M., Schryver, A., Struijs, J., Zelm, R., 2009. ReCiPe 2008, PRé Consultants. University of Leiden, Radboud University, RIVM, Nijmegen. Den Haag, The Netherlands: VROM (Dutch Ministry of Housing Spatial Planning and Environment).

Goh, K.C., Yang, J., 2009. Developing a life-cycle costing analysis model for sustainability enhancement in road infrastructure project. Rethinking Sustainable Development: Planning, Infrastructure Engineering, Design and Managing Urban Infrastructure, 324-331.

Goh, K.C., Yang, J., 2014. Managing cost implications for highway infrastructure sustainability. International Journal of Environmental Science and Technology 11(8), 2271-2280.

Gray, D., Laing, R., Docherty, I., 2016. Delivering lower carbon urban transport choices: European ambition meets the reality of institutional (mis)alignment. Environment and Planning A: Economy and Space 49(1), 226-242.

Green, R.J., Lepkowski, W., 2006. A Forgotten Model for Purposeful Science. Issues in Science and Technology 22(2), 69-73.

Guo, S., Hu, J., Dai, Q., 2018. A critical review on the performance of portland cement concrete with recycled organic components. Journal of Cleaner Production 188, 92-112.

Han, D., Do, M., 2015. Life Cycle Cost Analysis on pavement inspection intervals considering maintenance work delay. KSCE Journal of Civil Engineering 19(6), 1716-1726.

Hasan, U., 2015. Experimental study on bentonite stabilisation using construction waste and slag, Department of Civil Engineering. Curtin University, Perth, Western Australia, Australia, p. 181.

Hasan, U., Chegenizadeh, A., Budihardjo, M., Nikraz, H., 2015. A review of the stabilisation techniques on expansive soils. Australian Journal of Basic \& Applied Sciences 9(7), 541-548.

Hasan, U., Chegenizadeh, A., Budihardjo, M.A., Nikraz, H., 2016a. Experimental Evaluation of Construction Waste and Ground Granulated Blast Furnace Slag as Alternative Soil Stabilisers. Geotechnical and Geological Engineering 34(6), 1707-1722.

Hasan, U., Chegenizadeh, A., Budihardjo, M.A., Nikraz, H., 2016b. Shear Strength Evaluation Of Bentonite Stabilised With Recycled Materials. Journal of GeoEngineering 11(2), 59-73.

Hasan, U., Whyte, A., Al Jassmi, H., 2018a. Public-Transport System Management: Improving Service Satisfaction and Sustainable Uptake. Manuscript submitted.

Hasan, U., Whyte, A., Al Jassmi, H., 2018b. Travel pattern behaviour in intra-city transportation systems: A market-based association algorithm for data mining. Manuscript submitted.

Hood, C., Laing, R., Gray, D., Napier, L., Simpson, A., Tait, E., 2018. The application of major road infrastructure to support and drive sustainable urban mobility, 1st International Conference on New Horizons in Green Civil Engineering (NHICE-01). Victoria, BC, Canada.

Hoy, M., Rachan, R., Horpibulsuk, S., Arulrajah, A., Mirzababaei, M., 2017. Effect of wettingdrying cycles on compressive strength and microstructure of recycled asphalt pavement - Fly ash geopolymer. Construction and Building Materials 144, 624-634.

Huang, Y., Bird, R.N., Heidrich, O., 2007. A review of the use of recycled solid waste materials in asphalt pavements. Resources, Conservation and Recycling 52(1), 58-73. 
Huijbregts, M.A.J., Steinmann, Z.J.N., Elshout, P.M.F., Stam, G., Verones, F., Vieira, M., Zijp, M., Hollander, A., van Zelm, R., 2017. ReCiPe2016: a harmonised life cycle impact assessment method at midpoint and endpoint level. The International Journal of Life Cycle Assessment 22(2), 138-147.

Inyim, P., Pereyra, J., Bienvenu, M., Mostafavi, A., 2016. Environmental assessment of pavement infrastructure: A systematic review. Journal of Environmental Management 176, 128-138.

IPCC, 2008. Climate Change 2007: The Physical Science Basis. Contribution of Working Group I, II and III to the Fourth Assessment Report of the IPCC. Intergovernmental Panel on Climate Change, Geneva, Switzerland.

ISO 14025, 2006. Environmental labels and declarations -- Type III environmental declarations -Principles and procedures. International Organization for Standardization, Geneva, Switzerland, p. 25.

ISO 14040, 2006. Environmental Management - Life Cycle Assessment - Principles and Framework. International Organization for Standardization, Geneva, Switzerland, p. 20.

ISO 21930, 2017. Sustainability in buildings and civil engineering works -- Core rules for environmental product declarations of construction products and services. International Organization for Standardization, Geneva, Switzerland, p. 80.

Jannat, G.-E.-., Tighe, S.L., 2016. Investigating life cycle cost analysis to identify a sustainable pavement maintenance and rehabilitation strategy: A case study on Ontario highways, Efficient Transportation-Managing the Demand-2016 Conference and Exhibition of the Transportation Association of Canada. Transportation Association of Canada, Toronto, Ontario, p. 22.

Jiang, B., Liang, S., Peng, Z.-R., Cong, H., Levy, M., Cheng, Q., Wang, T., Remais, J.V., 2017. Transport and public health in China: the road to a healthy future. The Lancet 390(10104), 1781-1791.

Jingning, Y., 2015. The Evaluation Model of the Bridge Approach Design Scheme Based on the Life, 2015 8th International Conference on Intelligent Computation Technology and Automation (ICICTA). pp. 967-970.

Josa, A., Aguado, A., Heino, A., Byars, E., Cardim, A., 2004. Comparative analysis of available life cycle inventories of cement in the EU. Cement and Concrete Research 34(8), 1313-1320.

Jullien, A., Proust, C., Martaud, T., Rayssac, E., Ropert, C., 2012. Variability in the environmental impacts of aggregate production. Resources, Conservation and Recycling 62, 1-13.

Karlsson, C.S.J., Miliutenko, S., Björklund, A., Mörtberg, U., Olofsson, B., Toller, S., 2017. Life cycle assessment in road infrastructure planning using spatial geological data. The International Journal of Life Cycle Assessment 22(8), 1302-1317.

Klöpffer, W., 2006. The Hitch Hiker's Guide to LCA - An orientation in LCA methodology and application. The International Journal of Life Cycle Assessment 11(2), 142-142.

Laboratory, N.R.E., 2011. U.S. Life Cycle Inventory Database. National Renewable Energy Laboratory, Colarado, USA.

Lee, E.-B., Thomas, D., Alleman, D., 2018. Incorporating Road User Costs into Integrated LifeCycle Cost Analyses for Infrastructure Sustainability: A Case Study on Sr-91 Corridor Improvement Project (Ca). Sustainability 10(1), 179. 
Lee, J., Edil, T., Tinjum, J., Benson, C., 2010. Quantitative assessment of environmental and economic benefits of recycled materials in highway construction. Transportation Research Record: Journal of the Transportation Research Board(2158), 138-142.

Lippiatt, B.C., 2007. Building for environmental and economic sustainability technical manual and user guide (BEES 4.0). National Institute of Standards and Technology, Technology Administration, U.S. Department of Commerce, Washington, DC.

Lopez-Uceda, A., Ayuso, J., Jiménez, J.R., Galvín, A.P., Del Rey, I., 2018. Feasibility study of roller compacted concrete with recycled aggregates as base layer for light-traffic roads. Road Materials and Pavement Design, 1-13.

Lundberg, K., Miliutenko, S., Birgirsdottir, H., Toller, S., Brattebø, H., Potting, J., 2013. LICCER model guidelines report, Life cycle considerations in EIA of road infrastructure. ERA-NET ROAD. European Commission, p. 42.

Marceau, M., Nisbet, M.A., Van Geem, M.G., 2007. Life cycle inventory of Portland cement concrete. Portland Cement Association, Skokie, Illinois, p. 121.

Meil, J., 2006. A life cycle perspective on concrete and asphalt roadways: embodied primary energy and global warming potential. Athena Research Institute, Ottawa, ON, p. 92.

Miliutenko, S., Björklund, A., Carlsson, A., 2013. Opportunities for environmentally improved asphalt recycling: the example of Sweden. Journal of Cleaner Production 43, 156-165.

Mirza, S., Ali, M.S., 2017. Infrastructure crisis - a proposed national infrastructure policy for Canada. Canadian Journal of Civil Engineering 44(7), 539-548.

Mirzadeh, I., Butt, A.A., Toller, S., Birgisson, B., 2014. Life cycle cost analysis based on the fundamental cost contributors for asphalt pavements. Structure and Infrastructure Engineering 10(12), 1638-1647.

Mitchell, C., 2012. Aggregate carbon demand: the hunt for low carbon aggregate, in: Hunger, E.H., Walton, G. (Eds.), 16th Extractive industry geology conference. Extractive Industry Geology Conferences Ltd, Portsmouth, UK, pp. 93-99.

Mladenovič, A., Turk, J., Kovač, J., Mauko, A., Cotič, Z., 2015. Environmental evaluation of two scenarios for the selection of materials for asphalt wearing courses. Journal of Cleaner Production 87, 683-691.

Moretti, L., Mandrone, V., D'Andrea, A., Caro, S., 2018. Evaluation of the environmental and human health impact of road construction activities. Journal of Cleaner Production 172, 1004-1013.

Moretti, L., Mandrone, V., D'Andrea, A., Caro, S., 2017. Comparative "from cradle to gate" life cycle assessments of Hot Mix Asphalt (HMA) materials. Sustainability 9(3), 400.

Muñoz, I., Campra, P., Fernández-Alba, A.R., 2010. Including CO2-emission equivalence of changes in land surface albedo in life cycle assessment. Methodology and case study on greenhouse agriculture. The International Journal of Life Cycle Assessment 15(7), 672-681.

Noori, M., Tatari, O., Nam, B., Golestani, B., Greene, J., 2014. A stochastic optimization approach for the selection of reflective cracking mitigation techniques. Transportation Research Part A: Policy and Practice 69, 367-378. 
Officina dell'Ambiente, 2013. Dichiarazione Ambientale di Prodotto (EPD) delle materie prime seconde o aggregati di origine industriale. Italy, p. 12.

Oltean-Dumbrava, C., Watts, G., Miah, A., 2013. Transport infrastructure: making more sustainable decisions for noise reduction. Journal of Cleaner Production 42, 58-68.

Pant, P., Harrison, R.M., 2013. Estimation of the contribution of road traffic emissions to particulate matter concentrations from field measurements: A review. Atmospheric Environment 77, 78-97.

Pasandín, A.R., Pérez, I., 2017. Fatigue performance of bituminous mixtures made with recycled concrete aggregates and waste tire rubber. Construction and Building Materials 157, 26-33.

Qiao, Y., Dawson, A.R., Parry, T., Flintsch, G.W., 2015. Evaluating the effects of climate change on road maintenance intervention strategies and Life-Cycle Costs. Transportation Research Part D: Transport and Environment 41, 492-503.

Rahman, S.M., Khondaker, A.N., Hasan, M.A., Reza, I., 2017. Greenhouse gas emissions from road transportation in Saudi Arabia - a challenging frontier. Renewable and Sustainable Energy Reviews 69, 812-821.

Rangaraju, P.R., Amirkhanian, S., Guven, Z., 2008. Life Cycle Cost Analysis for Pavement Type Selection. South Carolina Department of Transportation, Washington, DC.

Regional Council Office for Infrastructure and Mobility, 2013. New official regional price list for public works. Sicilian Region.

RMCG Consultants for Business, C.a.E., 2010. Sustainable aggregates for South Australia-CO2 emission factor study. Zero Waste, South Australia, Victoria, Australia.

RMIT, 2007. Life cycle assessment tools in building and construction.

Sadri, A., Ardehali, M.M., Amirnekooei, K., 2014. General procedure for long-term energyenvironmental planning for transportation sector of developing countries with limited data based on LEAP (long-range energy alternative planning) and EnergyPLAN. Energy 77, 831-843.

Safi, M., Sundquist, H., Karoumi, R., 2014. Cost-efficient procurement of bridge infrastructures by incorporating life-cycle cost analysis with bridge management systems. Journal of Bridge Engineering 20(6), 04014083.

SAIC, S.A.I.C., 2006. Life Cycle Assessment: Principles and Practice, in: Curran, M.A. (Ed.). National Risk Management Research Laboratory, Cincinnati, OH, pp. iv, 88.

Sánchez, M., López-Mosquera, N., Lera-López, F., Faulin, J., 2018. An Extended Planned Behavior Model to Explain the Willingness to Pay to Reduce Noise Pollution in Road Transportation. Journal of Cleaner Production 177, 144-154.

Santos, G., Behrendt, H., Teytelboym, A., 2010. Part II: Policy instruments for sustainable road transport. Research in Transportation Economics 28(1), 46-91.

Santos, J., Ferreira, A., Flintsch, G., 2015. A life cycle assessment model for pavement management: road pavement construction and management in Portugal. International Journal of Pavement Engineering 16(4), 315-336. 
Santos, J., Thyagarajan, S., Keijzer, E., Flores, R.F., Flintsch, G., 2017. Comparison of Life-Cycle Assessment Tools for Road Pavement Infrastructure. Transportation Research Record: Journal of the Transportation Research Board 2646, 28-38.

Sharma, A., Saxena, A., Sethi, M., Shree, V., Varun, 2011. Life cycle assessment of buildings: A review. Renewable and Sustainable Energy Reviews 15(1), 871-875.

Sheehan, J., Camobreco, V., Duffield, J., Graboski, M., Shapouri, H., 1998. Life cycle inventory of biodiesel and petroleum diesel for use in an urban bus. U.S. Department of Agriculture and U.S. Department of Energy, United States, p. 286.

Silva, R.V., de Brito, J., Dhir, R.K., 2015. The influence of the use of recycled aggregates on the compressive strength of concrete: a review. European Journal of Environmental and Civil Engineering 19(7), 825-849.

Simões, D., Almeida-Costa, A., Benta, A., 2017. Preventive maintenance of road pavement with microsurfacing - an economic and sustainable strategy. International Journal of Sustainable Transportation 11(9), 670-680.

Stranddorf, H.K., Hoffmann, L., Schmidt, A., 2005. Impact categories, normalisation and weighting in LCA. Danish Ministry of the Envrionment - Environmental Protection Agency, Luxembourg.

Stripple, H., 2001. Life cycle assessment of road. A pilot study for inventory analysis, A pilot study for inventory analysis. Rapport IVL S, 2nd ed. IVL - Swedish Environmental Research Institute, Gothenburg, Sweden, p. 96.

Susca, T., 2012. Enhancement of life cycle assessment (LCA) methodology to include the effect of surface albedo on climate change: Comparing black and white roofs. Environmental Pollution 163, 4854.

Svoboda, S., 2006. Note on life cycle analysis, Pollution prevention in a corporate strategy. National Pollution Prevention Centre for Higher Education, University of Michigan Press, Ann Arbor, Michigan, p. 9.

Toller, S., Kotake, M., Nyholm, S., 2014. Klimatkalkyl version 2.0-Beräkning av infrastrukturens klimatpåverkan och energianvändning i ett livscykelperspektiv (in Swedish)(Klimatkalkyl version 2.0 - calculation of the infrastructure's impact on climate change and energy use in a life cycle perspective). Trafikverket, Sweden.

Treloar, G.J., Love, P.E., Crawford, R.H., 2004. Hybrid life-cycle inventory for road construction and use. Journal of Construction Engineering and Management 130(1), 43-49.

Trigaux, D., Wijnants, L., De Troyer, F., Allacker, K., 2017. Life cycle assessment and life cycle costing of road infrastructure in residential neighbourhoods. The International Journal of Life Cycle Assessment 22(6), 938-951.

Turk, J., Mauko Pranjić, A., Mladenovič, A., Cotič, Z., Jurjavčič, P., 2016. Environmental comparison of two alternative road pavement rehabilitation techniques: cold-in-place-recycling versus traditional reconstruction. Journal of Cleaner Production 121, 45-55.

Union Nationale des Producteurs de Granulats, 2012. Module D'informations Environnementales de la Production de Granulats Recyclés. Union Nationale des Producteurs de Granulats, Paris, France, p. 11. 
Wang, C., Wei, Y., 2015. A study on calculation method of CO2 emission discharged from the producing of asphalt. North. Commun. 6, 90-93.

Wang, M.Q., 2011. Greenhouse gases, regulated emissions, and energy use in transportation. Argonne National Laboratory.

Wang, T., Lee, I.-S., Kendall, A., Harvey, J., Lee, E.-B., Kim, C., 2012. Life cycle energy consumption and GHG emission from pavement rehabilitation with different rolling resistance. Journal of Cleaner Production 33, 86-96.

Wang, T., Xiao, F., Zhu, X., Huang, B., Wang, J., Amirkhanian, S., 2018. Energy consumption and environmental impact of rubberized asphalt pavement. Journal of Cleaner Production 180, 139-158.

Wennström, J., Karlsson, R., 2016. Possibilities to reduce pavement rehabilitation cost of a collision-free road investment using an LCCA design procedure. International Journal of Pavement Engineering 17(4), 331-342.

Whyte, A., 2015a. Integrated design and cost management for civil engineers. CRC Press, New York, USA.

Whyte, A., 2015b. Life-Cycle Cost Analysis of Built Assets-LCCA Framework, 1 ed. Verlag Dr Müller (VDM), Saarbrücken, Germany.

Wu, D., Yuan, C., Liu, H., 2017. A risk-based optimisation for pavement preventative maintenance with probabilistic LCCA: a Chinese case. International Journal of Pavement Engineering 18(1), 11-25.

Yu, B., Lu, Q., 2012. Life cycle assessment of pavement: Methodology and case study. Transportation Research Part D: Transport and Environment 17(5), 380-388.

Yu, B., Lu, Q., 2014. Estimation of albedo effect in pavement life cycle assessment. Journal of Cleaner Production 64, 306-309.

Yu, B., Wang, S., Gu, X., 2018. Estimation and uncertainty analysis of energy consumption and CO2 emission of asphalt pavement maintenance. Journal of Cleaner Production 189, 326-333.

Zhang, Y., Liu, W., 2015. Analysis of energy consumption and $\mathrm{CO}_{2}$ emission of asphalt pavement construction materials in construction period. Highway 1(2015), 100-107.

Zhao, J., Zheng, Z., Cao, Z., Yao, J., 2016. Spatial and causal analysis of discrepancies in CO2 emission factors for cement production among provinces in China. Resour. Sci. 38, 1791-1800.

Zimmerman, K., Smith, K., Grogg, M., 2010. Applying Economic Concepts from an LCCA to a Pavement Management Analysis, 89th Annual Meeting of the Transportation Research Board. Washington, DC. 